\title{
SOBREPOSIÇÃO TERRITORIAL: ÁREA DE CONSERVAÇÃO TOTAL E TERRAS COMUNITÁRIAS NA SERRA DA GORONGOSA EM MOÇAMBIQUE
}

\author{
TERRITORIAL OVERLAY: TOTAL CONSERVATION AREA AND COMMUNITY LAND IN SERRA DA GORONGOSA IN \\ MOZAMBIQUE
}

\begin{abstract}
"Espaços, territórios e lugares, cada um a seu modo demandam apropriações do outro, produzem subjetivações, metaforizam seus próprios sentidos, propõem discursos sem parar" (NOLASCO, 2010, p. 124).
\end{abstract}

\section{RESUMO}

A Serra da Gorongosa é uma Área de Conservação Total, criada pelo Governo de Moçambique, através do Decreto Ministerial 78/2010 de 31 de Dezembro, com o propósito de ampliar os limites do Parque Nacional da Gorongosa e assegurar a geoconservação. A criação da Área de Conservação Total em terras ocupadas, secularmente, pelas comunidades de Canda, Murombodzi, Nhambirira e Nhancuco, propriedades privadas de pequenos agricultores, áreas detentoras de licenças de prospecção mineira e de concessão florestal traz, à ribalta, a discussão sobre as sobreposições territoriais na Serra da Gorongosa. A pesquisa pretende, pois, contribuir no debate sobre as sobreposições territoriais das áreas de conservação em terras comunitárias, perspectivando trazer uma reflexão no que concerne à relação entre natureza-sociedade, através do território. A nossa contribuição resulta da combinação metodológica de revisão bibliográfica e do trabalho do campo, o que nos permitiu concluir que, em Moçambique, o debate relativo à sobreposição territorial das áreas de conservação em terras comunitárias é incipiente e longe de encontrar consensos.

Palavras-chave: Serra da Gorongosa, Área de Conservação Total, Terras Comunitárias, Sobreposição territorial, Recursos Naturais.

\section{ABSTRACT}

The Serra de Gorongosa is total a Conservation Area, created by the Government of Mozambique, through the Ministerial Decree $n^{\circ} 78 / 2010$ of December 31, with the purpose of expanding the boundaries of the Gorongosa National Park and ensuring Geo-conservation. The creation of the total Conservation Area on the land occupied, for centuries, by the communities of Canda, Murombodzi, Nhambirira and Nhancuco, private properties of small farmers, areas holding miming prospecting licenses and forest concession, bring to spotlight, the discussion about territorial overlaps in the Gorongosa Mountain range. The research intends, therefore, to contribute to the debate on territorial overlaps of conservation areas on community lands, aiming to bring a reflection with regard to the relationship between nature and society, through the territory. Our contribution results from the methodological combination of literature review and fieldwork, which allowed us to conclude that, in Mozambique, the debate on territorial overlap of Conservation Areas on community lands is incipient and far from finding consensus

Keywords: Gorongosa Mountain Range, Total Conservation Area, Community land, Territory overlap, Natural Resources.

\section{Raimundo Alberto Mulhaisse ${ }^{a}$}

a Universidade Licungo (UniLicungo), Beira, Moçambique

DOI: $10.12957 /$ geouerj.2020.53915

Correpondência: mulhaisse@gmail.com

Recebido em: 24 mai. 2019

Revisado em: 11 abr. 2020

Aceito em: 4 mai. 2020 


\section{INTRODUÇÃO}

A criação de áreas de conservação constitui uma das principais formas de intervenção dos governos, no intuito de minimizar as perdas da biodiversidade ante a degradação ambiental imposta pelas ações antrópicas nefastas. Porém, áreas de conservação, no mundo, têm sido criadas em territórios ocupados pelos assentamentos populacionais, particularmente nos países pobres, ocasionando o fenômeno de sobreposição territorial.

A sobreposição territorial consiste na existência de diferentes interesses e ordenamentos que disputam hegemonia em uma única área específica. Revela duas frentes que se opõe pela disputa de terras associadas à exploração dos recursos naturais que ocorrem em escala tanto nas áreas de consenvação quanto nas terras comunitárias. A discussão sobre a sobreposição territorial tende a ficar no plano das acusações, insinuando a existência deliberada da área ambiental com o objetivo de suprimir os direitos das comunidades locais ou destas em inviabilizar a criação e fortalecimento das áreas de conservação (SANTILLI, 2005).

Em Moçambique o governo criou, na Serra da Gorongosa, a Área de Conservação Total em terras ocupadas pelas comunidades de Canda, Murombodzi, Nhambirira e Nhancuco e integrou-a ao Parque Nacional da Gorongosa (PNG) para a sua gestão ambiental.

A integração da Serra da Gorongosa ao PNG colocou a presença secular das comunidades locais ${ }^{1}$ em situação de expropriação dos recursos naturais e de exposição às ações de desencorajamento de sua permanência na Área de Conservação Total desencadeadas pelos gestores do PNG.

As novas formas de apropriação do território influenciam a relação entre os três principais atores sociais. No centro encontramos as comunidades que, habitando no interior e a volta da Serra da Gorongosa, desenvolvem diversas atividades de apropriação dos recursos naturais para a sua subsistência, com destaque para a prática agrícola e estabelecem fortes laços culturais com o seu território.

A localização da Serra da Gorongosa no território moçambicano coloca, em si mesma, em evidência um segundo e fundamental ator social - o Estado de Moçambique e seu modelo disciplinador - como sujeito coletivo de representação internacional, sendo, pois, ator de suma importância na produção e transformação do espaço geográfico. Deste modo, os dilemas daqueles que vivem no interior de um Estado Soberano, afetam e são afetados, de uma maneira ou de outra, pelas determinações dos governos sob os quais as comunidades se subordinam rigorosamente.

\footnotetext{
1 De acordo com o ponto 1, artigo 1 da Lei de Terras (Lei 19/97 de 1 de Outubro), as comunidades locais são definidas como agrupamentos de famílias e indivíduos, vivendo numa circunscrição territorial de nível de localidade ou inferior, que visam a salvaguarda de interesses comuns através de protecção de áreas habitacionais, áreas agrícolas, sejam cultivadas ou em pousio, florestas, sítios de importância cultural, pastagens, fontes de água e áreas de expansão.
} 
Na sequência do instituído pelo Decreto do Conselho de Ministros de Moçambique², que considera a Área de Conservação Total da Serra da Gorongosa sob a gestão ambiental do PNG, surge um terceiro ator social, a CARR FUNDATION, uma Organização-não-governamental (ONG) americana. É nosso entendimento que este ator social, de uma maneira ou de outra, faz a mediação entre as necessidades e formas de exercício político das comunidades que habitam a Serra da Gorongosa e os mecanismos de poder que identificam o Estado moçambicano.

O Estado de Moçambique vive, para além de suas contradições internas, a condição de ser um Estado da África Austral e, por isso, vê-se obrigado a realizar suas próprias leituras de contradições que dão identidade geral ao continente e ao mundo e, nesse contexto, do papel das chamadas "grandes potências" (EUA, China, UE e Brasil), com seus diversos e poderosos interesses na região - sem que possamos esquecer que, para uma boa leitura dos dilemas, os entendimentos internacionalizados do significado de "áreas de conservação" e "proteção da biodiversidade" estarão, sempre, influenciando tanto as determinações emanadas das ONG's quanto dos próprios organismos governamentais e internacionais envolvidos direta ou indiretamente no processo, por isso mesmo, definirão as formas de resistência das comunidades diretamente atingidas.

A Serra da Gorongosa, situada a cerca de $50 \mathrm{~km}$ a Noroeste do PNG e a aproximadamente $160 \mathrm{~km}$ da costa moçambicana, localiza-se no distrito da Gorongosa, província de Sofala em Moçambique e na parte meridional da África, conforme figura 1:

Figura 1. Enquadramento geográfico da Serra da Gorongosa. Fonte: Elaborado pelo autor a partir da Base Cartográfica da DINAGECA.

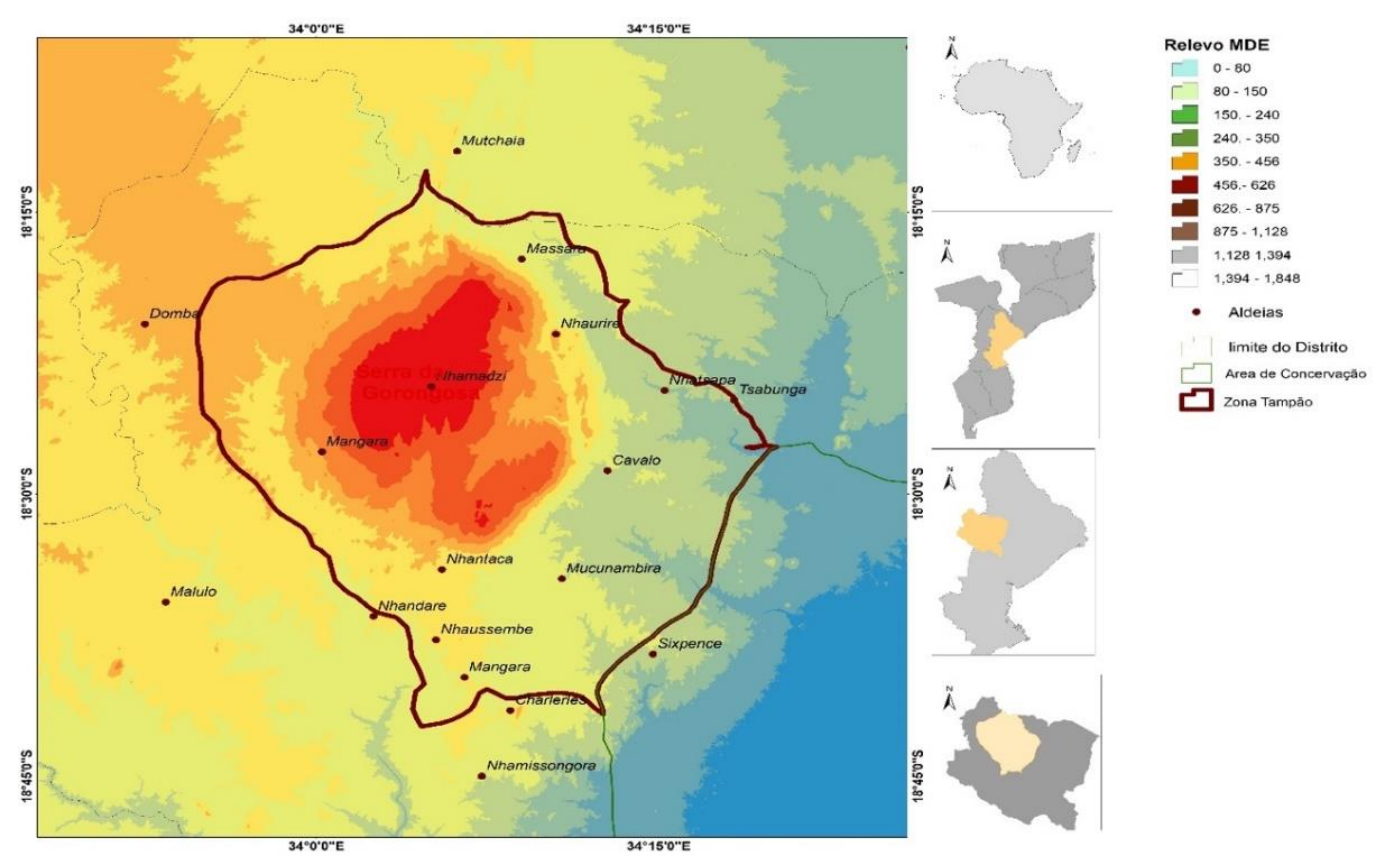

2 Decreto no 78/2010 de 31 de Dezembro. 
A Serra, com cerca de $10.000 \mathrm{~km}^{2}$ de superfície ${ }^{3}$, abriga inúmeros atores sociais com interesses díspares pela apropriação, controlo e exploração dos recursos naturais.

\section{Serra da Gorongosa e história da sua ocupação}

A história da ocupação da Serra da Gorongosa começa e ser contada quando teriam chegado e se estabelecido os primeiros povos de origem e proveniência diversificada. As diferentes leituras do acervo bibliográfico, tais como Invez e Freitas (1971), Pelissier (1994), Serra (2000), Adg (2006), Santos (2007) e Cabaço (2009) e as entrevistas aos membros das comunidades locais facultaram-nos a percepção de que os seus residentes compõem dois grupos populacionais.

O primeiro é conhecido como população sena, do grupo étnico magorongoze. Este grupo habita a Serra desde o século XIX, trabalha a terra para fins de auto sustento e é fortemente influenciado por determinadas práticas socioculturais orientadas para a conservação dos recursos naturais.

O segundo grupo populacional fez-se à Serra da Gorongosa, tendo lá se fixado na fase posterior ao 1o conflito armado (1976-1992), ou seja, a partir deste período, a Serra passou a testemunhar o fluxo de pessoas provenientes de diferentes distritos, particularmente dos das províncias de Sofala e de Manica à busca de terras férteis para a prática agrícola e exploração artesanal de ouro, com fins comerciais.

A relação vivenciada entre estes grupos populacionais foi pacífica, mas com desconfianças inicialmente em relação aos vindouros. A designação da área para o cultivo e/ou para a fixação habitacional foi sempre com a permissão das lideranças comunitárias e a circulação dos vindouros e dos visitantes a determinados lugares, incluindo os sagrados, teve sempre limitações, às quais só eram permitidos, no período diurno, após um ritual e/ou acompanhados por um guia, normalmente parente do régulo ou depois de os primeiros ganharem confiança absoluta em relação aos "estranhos":

\footnotetext{
Quando nos foi autorizada a nossa fixação residencial neste local, foi nos dito que existiam lugares sagrados nos quais repousam os antepassados e que neles, determinadas práticas deveríamos nos prescindir de realizá-los, como por exemplo entrar ou passar próximo dos bosques e, em caso de inobservância de certos princípios, poderíamos ser confrontados com os donos da terra encarnados em animais ferozes (leão, leopardo ou perdermo-nos na Serra, podendo sair muito distante do lugar onde pretendemos ir" [EMC2,8].
}

Contudo, a situação relacionada com os que iam se fixando na Serra foi perdendo vigor, ao mesmo tempo que parte de população jovem ia abandonando-a para Vila-sede da Gorongosa, Nhamatanda, Chimoio e Beira e outros centros urbanos em geral.

\footnotetext{
3 De acordo com o Despacho do Ministro de Terra, Ambiente e Desenvolvimento Rural que aprova o Plano de Maneio do Parque Nacional da Gorongosa no Boletim da República - I Série 88, de 25 de Julho de 2016.
} 
A Serra é habitada por comunidades de Canda, Murombodzi, Nhambirira e Nhancuco que integram originalmente as etnias sena, chona e ndau, conforme vimos anteriormente, tendo se fundido e constituído o grupo étnico denominado por magorongoze.

O conceito de etnia, ganha importância geográfica quando nos remete à compreensão das espacialidades da cultura das comunidades locais, com suas diferentes referências ancestrais. A compreensão de existências, conforme emanam Silva (2016) e Silva e Mulhaisse (2016) remete-nos a importância de perceber as "geografias das existências" que se trata de compreender os atores sociais, suas espacialidades baseadas nos saberes locais que muitas vezes não são valorizados pelos gestores ambientais e pelo modelo de modernização ocidental ${ }^{4}$.

A língua predominantemente falada é Chinduma, vulgarmente conhecida por Chigorongozi (ADG, 2006, p.31). Não dispomos do número exato dos habitantes da Serra, uma vez que os limites da divisão políticoadministrativa das localidades não coincidem com os seus limites ecológicos. No entanto, segundo as informações que nos foram proporcionadas pelas lideranças comunitárias e pelo site do PNG, estima-se que na Serra da Gorongosa (curva de nível $>700$ metros) residam cerca de 500 famílias. Se considerarmos que o agregado familiar no distrito de Gorongosa tem, em média, 5 pessoas (INE, 2017), então acredita-se que a Área de Conservação seja habitada por cerca de 2.500 pessoas.

A administração do questionário aos chefes dos agregados familiares permitiu-nos reconhecer que a maioria dos habitantes nasceu na Serra da Gorongosa (88\%) e outros em Nhamatanda (6\%), Cheringoma (4\%) e Marromeu (2\%), como ilustra a figura 2.

Figura 2. Local de nascimento dos habitantes da Serra da Gorongosa por distrito. Fonte: Elaborado pelo autor.

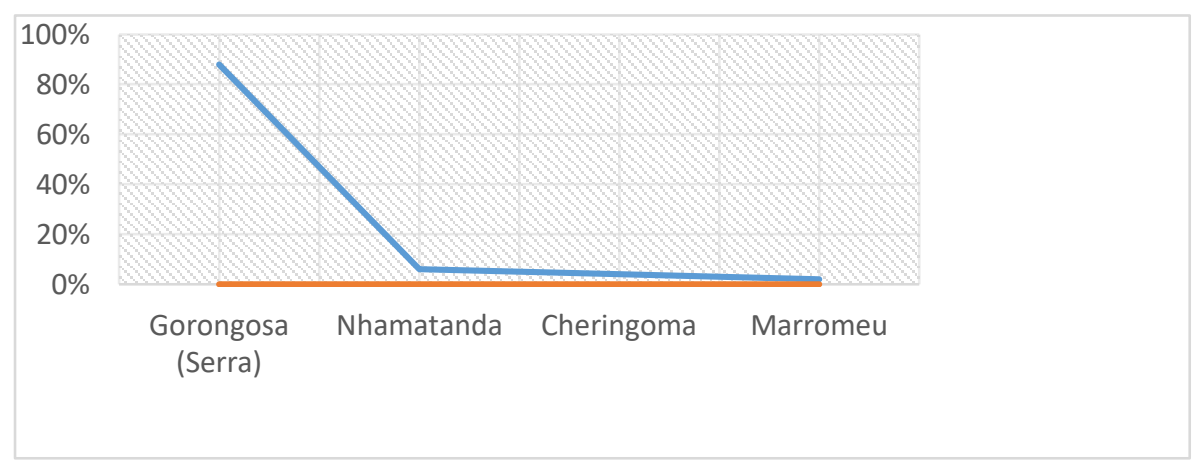

\footnotetext{
${ }^{4} \mathrm{O}$ modelo de modernização ocidental nega a riqueza cultural dos lugares e a capacidade de pensar no desenvolvimento a partir das culturais ancentrais locais. Propagam, em geral, um modelo de biodiversidade que nega a sociodiversidade, ou seja, apoiam se numa "natureza intocada", o que é um mito, como analisa o antropólogo brasileiro Antonio Diegues (2001).
} 
O questionário trouxe-nos também a informação sobre as faixas etárias dos habitantes da Serra, o que nos facultou compreender que a maioria (69\%) possui idade compreendida ente 41 e 50 anos, isto é, teria nascida antes do término do 10 conflito armado opondo a RENAMO e o Governo de Moçambique ${ }^{5}$, tal qual podemos observar na figura 3 :

Figura 3. Faixa etária dos residentes na SG (2012). Fonte: Elaborado pelo autor.

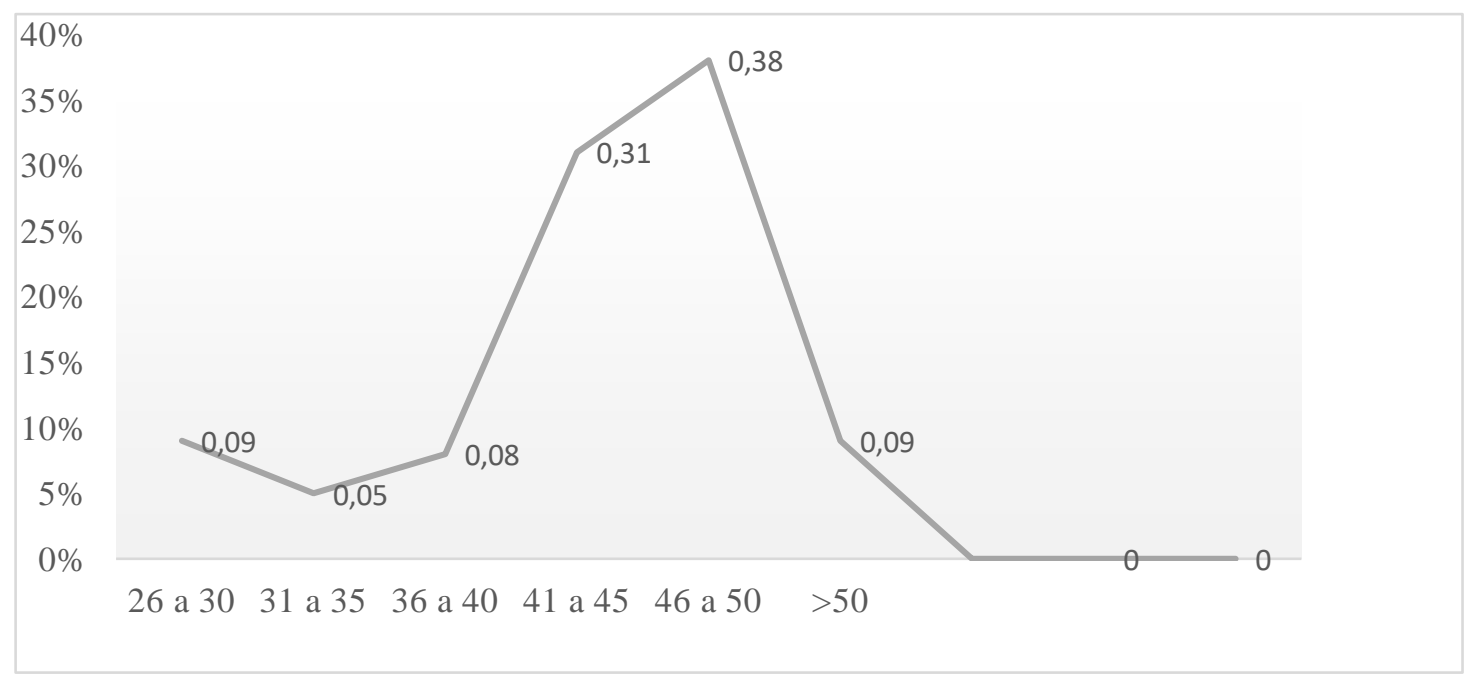

O grupo anteriormente referido não só nasceu na Serra como também, em sua maioria (86\%), constituiu nela suas famílias nucleares. Para fundamentarmos estes e outros resultados quantitativos aplicamos a entrevista aos habitantes da Serra da Gorongosa, onde obtemos as seguintes informações:

[...] eu nasci aqui na Serra e minha mulher também é daqui... meus filhos nasceram aqui [...] Meus pais também vivem aqui. Quase todos nascemos e casamos aqui. [...] e aqui trabalhamos a terra para nos alimentar $\left[\mathrm{EMC}_{3,7,9}\right]$.

O excerto do resumo dos relatos dos entrevistados confirma que a maioria dos habitantes terá nascido e constituído suas famílias nucleares na Serra da Gorongosa e a minoria proveniente dos distritos das províncias de Sofala e de Manica fundamentalmente, encontrando-se na Serra por várias razões, entre elas o trabalho assalariado nas quintas, casamento, busca de terras férteis para a prática agrícola e comercialização de seus produtos e exploração artesanal de ouro, conforme o seguinte extrato:

5 O 1o conflito armando ocorreu no período de 1976 a 1992. 
[...] eu não nasci na Serra, vim trabalhar para o meu boss ${ }^{6}$ que está na Beira, acabei gostando de ficar cá, conheci alguém e casei. Tenho um filho e metade $[$ [...]. Aqui é bom, porque não nos falta comida todo o ano e dá para produzir muito $\left[\mathrm{EMC}_{6}\right]$.

Um grupo de habitantes, não menos desprezível, possui idade superior a 50 anos (9\%) nasceu e permaneceu na Serra da Gorongosa, no decurso do 10 conflito armado. Este grupo resumidamente afirma o seguinte:

\footnotetext{
[...] nasci aqui, minha mulher... outros nossos irmãos também nasceram nesta Serra, mesmo com a guerra não podíamos sair daqui porque os nossos antepassados estão aqui sepultados, não os podemos abandonar, porque não teríamos sorte, são eles que nos protegem e por isso continuamos vivos [...]" $\left[\mathrm{EMC}_{2,4,10]}\right.$.
}

No excerto ora apresentado depreendemos o quão, parte das comunidades está culturalmente ligado ao seu território. Por último destacamos o grupo de habitantes com idade compreendida entre 26 e 40 anos (22\%), parte dos quais nasceram na Serra, no decurso do 1 으 conflito armado, desenvolve nela suas atividades de subsistência e afirmam que alguns dos seus parentes deixaram a Serra com o término das hostilidades militares, indo residir na vila-sede da Gorongosa, Chimoio, Nhamatanda e Beira.

\section{Organização social das comunidades locais}

Procuramos aqui perceber como os membros das comunidades locais se relacionam entre si, através das suas ações, e estabelecem a partilha de elementos e ideias comuns, interpretam as suas vidas no seio da comunidade e ajustam o seu comportamento na edificação da vida social.

À semelhança do que acontece em várias regiões rurais de Moçambique, na Serra da Gorongosa existem dois modelos de organização social, sendo um estatal, protagonizado pelas estruturas governamentais e outro tradicional, de reprodução social dos magorongoze (dominado por senas), o qual identitário da maioria dos seus habitantes.

No primeiro, o Chefe do Posto representa o Governo Central e no segundo o régulo é o líder supremo em cada uma das comunidades. Na sua governação, o régulo é apoiado pelos sapandas e fumos, em língua local. O cargo de sapanda é hereditário e normalmente atribuído a um ramo da família principal ou a família que, pela sua expressão numérica ou serviços prestados, tenha jus à distinção, enquanto o cargo de fumo não é hereditário e recai em indivíduos e não em famílias. No decurso das suas funções o fumo apoia-se geralmente nos anciões proeminentes $\left[\mathrm{EMC}_{3,6}\right]$.

\footnotetext{
${ }^{6} \mathrm{O}$ mesmo que patrão, na gíria popular moçambicana.

7 Mulher grávida, não significando necessariamente o período da gestação.
} 
O régulo detém o poder legislativo e os sapandas e fumos, o executivo. Cabe a estes fiscalizar o cumprimento das deliberações do régulo, as quais prevalecem sobre as de quaisquer outros pois, e de acordo com a afirmação de um dos entrevistados, o régulo é visto como "quem garante a vida espiritual da comunidade" [EMC 9 .

Ao régulo compete-Ihe zelar pelo bem-estar dos membros do seu regulado; nomear, advertir e destituir seus conselheiros além de decidir sobre a realização dos sembê (preces propiciatórios aos ancestrais). Em cada grupo de povoados ou comunidades encontramos esta organização social.

O grupo de povoado congrega várias famílias e indivíduos que não são exclusivamente aparentados e que coabitam o mesmo território, têm uma chefia e língua comum com práticas socioculturais e costumes, na sua essência, similares, ou seja, o grupo de povoado corresponde a uma dada comunidade. Os membros da comunidade encontram-se intensamente ligados por forte solidariedade grupal em volta do régulo, por razões de ordem afetiva e sobrenatural.

O desenvolvimento do grupo de povoado, implicando a sua expansão, é fortemente influenciado pelo exercício da autoridade político-administrativa, casamentos, exploração dos recursos naturais e tensão político-militar, concorrendo para a subdivisão do território e para a existência dos movimentos migratórios de um grupo para outro ou para fora dos quatro grupos de povoados.

A coexistência de dois modelos de governo em exercício (tradicional e estatal) coloca implicitamente em jogo duas forças antagônicas, sendo que a tradicional concorre para a união dos diferentes grupos em torno do seu poder e a administrativa que tende a desintegrar o poder tradicional.

A aplicação de questionário e entrevista permitiu verificar que pessoas residentes em terras possuídas pelas sedes dos Postos Administrativos e das Localidades tendem, nas suas opiniões e posições, a distanciarem-se do poder tradicional e a identificarem-se com o sistema administrativo. Porém, a autoridade administrativa busca o reconhecimento da importância e do papel agregador da autoridade tradicional e, por via disso, o estabelecimento de parceria entre os dois poderes. Esta informação é secundada pelos nossos entrevistados que reconhecem a existência de cooperação entre os dois modelos de organização social no processo de governança das comunidades locais.

Trabalhamos bem com governo aqui, não existe muitos problemas, participamos das reuniões com pessoas das brigadas do governo que vem da Beira ou de Maputo. Também mobilizamos pessoas do regulado para participar nas reuniões $\left[\mathrm{EMC}_{1,3,6}\right]$.

A observação do cotidiano das famílias e a participação em cerimônias religiosas para petição aos espíritos pela proteção da família/comunidade e prosperidade social, localmente conhecidas por sembê, 
propiciou-nos o reconhecimento da existência de sentimentos de dominância dos que detêm o "poder" perante os súbditos e o de veneração ao sagrado, o que inspira a confiança e esperança aos membros das comunidades.

A religião, expressa pelas práticas mágico-religiosas, constitui elemento essencial para a vida dos seus membros; influencia no pensamento, nas ações e em tudo que lhes incumbe fazer. Esta é reconhecida pelo sistema administrativo de tal modo que, em algumas circunstâncias, a título de exemplo, quando se pretende fazer o "lançamento de pedra" para a construção de um empreendimento social, o governo e as ONG's fazem concessões aos condicionalismos impostos por estas práticas, fazendo o sembê conduzido pelas pessoas que detêm o "poder" nas comunidades.

\footnotetext{
O régulo costuma dirigir cerimónias tradicionais para o governo, quando este pede para fazer ou quando acha que determinado projeto a ser desenvolvido em benefício da comunidade ou no nosso território precisa de cerimónia para ser bem recebido pelos espíritos e evitar problemas, no futuro $\left[\mathrm{EMC}_{1,6}\right]$.
}

Na Serra as árvores, os animais, os homens detêm "poderes" distintos que influenciam seus membros, uma vez que estão permanentemente expostos a estes, "determinando" o sucesso ou insucesso das vidas dos membros das comunidades. Para estas comunidades tem "poder" quem detêm "forças mágicas" ou sobrenaturais. É comum ouvir-se que certo leão ou leopardo encarna determinados líderes que em vida tinham poder sobrenatural. A estes animais não se deve, de forma alguma, matá-los sob o risco de "trazer azar para a família ou comunidade" [ $\left.\mathrm{EMC}_{3}\right]$. Trata-se, no entanto, de animais raros na região, o que poderá ser um mecanismo para a sua preservação.

A coesão entre os membros do grupo ou da comunidade depende da "força" e da qualidade do "poder" que seu líder possui sobre os seguidores. Explica-se assim, que as lideranças comunitárias usufruam de relativa reputação, ou seja, estes têm também "poder" sobrenatural, cabendo-lhes, deste modo, o papel de orientarem as cerimônias tradicionais e, quando não se obtêm os resultados desejados, então considera-se que o seu líder tem "poder" limitado para controlar esta ou aquela situação e aí recorre-se aos que detêm "poderes" com "maior força", o mesmo que dizer com forças excepcionais, mas que sejam membros daquelas comunidades. Por conseguinte "quando existe estiagem e a chuva tarda a aparecer existem líderes detentores de "poderes" que conseguem fazer cair a chuva a partir do sembê, dado o seu "poder" de "maior força" $\left[\mathrm{EMC}_{3,6}\right]$.

Mas o "poder" pode ser ostentado por qualquer um que passe por um "preparo" junto dos que têm capacidades de manipular técnicas mágicas, trata-se, pois, de "poder adquirido". Normalmente, as pessoas da terceira idade, eleitas na família, têm "poderes" porque acumulam "forças" que acresceram às que herdaram das gerações precedentes, ou seja, o indivíduo e o seu "poder" não deixam de existir depois da sua morte. No 
entanto, nem todos os ancestrais dispõem do mesmo "poder" e por isso nem todos são recordados e invocados de igual forma (Ivens e Freita, 1971, p. 72).

O "poder" exercido por aqueles que o detêm parece ficar fortalecido graças ao mecanismo de educação tradicional que se alicerça em contos tradicionais, tabus e práticas mágico-religiosas, fundamental para a vida das comunidades, por possuir a capacidade de influenciar o comportamento e as atitudes dos seus membros.

As comunidades acreditam que os antepassados representam os seus "deuses" e estes revelam-se aos seus parentes sob forma de serpentes e outros animais como Panthera leo (leão), Panthera pardus (leopardo) e Crocuta (hiena), nas imediações dos lugares sagrados ${ }^{8}$.

Acedemos a 7 (sete) lugares sagrados ${ }^{9}$, nomeadamente as cascatas de Murombodzi e Nhamu e as florestas sagradas de Chitunga, Cucuia, Gogogo, Phacolacanga e Samatenge. Para efeito, fomos submetidos a um ritual típico orientado pelo régulo, no qual este suplicou aos espíritos a nossa proteção, no decurso de visita aos lugares sagrados, numa cerimônia denominada por sembêt $\hat{~}^{10}$

A sembê é feita na presença de fumos, sapandas e membros da família do régulo, das comunidades e visitantes. Acredita-se que, caso não passe por aquela cerimônia, o $(\mathrm{s})$ visitante $(\mathrm{s})$ fica $(\mathrm{m})$ desprotegido $(\mathrm{s})$ contra os ataques pelos animais ferozes, no decurso da visita a ser feita. Para a cerimônia são atraídos os seguintes produtos: bebidas (1 garrafão/garrafa de vinho, 1 caixa de cerveja, 1 caixa de refresco), maço de cigarros, caixa de fósforo, 5 pães, 1 pacote de bolacha, $1 \mathrm{~kg}$ de farinha, $1 \mathrm{~kg}$ de açúcar, pedaço de pano branco, preto ou vermelho que poderão ser substituídos pelo papel branco, 4 copos de vidro e 200,00 MT (cerca de 3,0 dólares americanos).

No local da realização da cerimônia, os participantes que têm o calçado, descalçam-no, juntam-se aos restantes e acercam-se da palhota, em seguida, sentam-se de forma ordeira e em silêncio no seu exterior, enquanto o mestre da cerimônia (régulo) se dirige aos espíritos, no interior da palhota, acompanhado de pessoas mais próximas do régulo.

O mestre da cerimônia estende o pedaço do pano ou papel e, por cima deste coloca copos bemdispostos. Em seguida, despeja lentamente a farinha sobre o pano, em forma de montanha, contida na mão esquerda apoiada pela direita, vai evocando os espíritos e pedindo o consentimento para a visita aos lugares

\footnotetext{
8 Os lugares sagrados são espaços impregnados de simbolismo, reivindicados, apossados e produzidos pelas comunidades religiosas, pois as suas atividades religiosas e seus valores simbólicos encontram-se intrinsecamente relacionados a estes (ROSENDAHL, 2012). ${ }^{9} \mathrm{~A}$ construção do lugar sagrado "ocorre por meio de processos simbólicos que refletem as características emocionais associadas às qualidades físicas do lugar" ROSENDAHL (2012, p.75) apud. ELIADE (1959).

${ }^{10}$ A sembê constitui uma manifestação da religião que, de acordo com JUNOD (1996), compreende todos os ritos, concepções ou sentimentos que passam pela crença em espíritos pessoais, semi-pessoais ou coletivos revestidos dos atributos de divindade. Enquadra-se nas práticas mágico-religiosas e consiste em uma cerimônia de evocação aos espíritos conduzida geralmente pelo régulo em sua casa, com o intuito de suplicar-Ihes a "visita" aos lugares sagrados pelo Muzungo (visitante).
} 
sagrados e defesa contra os animais ferozes, ao ritmo das palmas cadenciadas que se estende no decurso da cerimônia. Seguidamente pega no tabaco em pó (rapé) e vai igualmente despejando lentamente no pedaço do pano ou papel, enquanto continua a se "comunicar" com os antepassados.

Do maço de cigarros, o mestre subtrai um, acende-o e o dispõe sobre a farinha despejada no pedaço do pano ou papel, no qual também coloca pão desfeito em pedaços e, por fim, serve o vinho em um dos copos e derrama parte de seu conteúdo no chão, evocando os nomes de alguns dos antepassados e descrevendo a vida e hierarquia dos antepassados que reproduz a imagem da estrutura social à superfície.

O término da cerimônia coincide com o bater das palmas pelo régulo de mãos ligeiramente fechadas, dando um som abafado, que se integra na cadência dos restantes. Após este ato é permitido aos visitantes o acesso aos distintos lugares sagrados, particularmente os de lazer (cascatas de Murombodzi e Nhamu) e a liberdade de os fotografar.

A visita aos lugares sagrados é realizada com um acompanhante, confiado pelo régulo, a quem lhe cabe o papel de conduzir os visitantes, explicar-Ihes a importância sociocultural dos lugares sagrados para as comunidades locais e advertir-lhes sobre algumas precauções e restrições.

Os lugares sagrados denunciam níveis mínimos de intervenção humana, sendo caracterizados por apresentarem uma vegetação frondosa que garante o alimento e o abrigo para a biodiversidade local, de ordem animal. Constituem, pois, um contraste conspícuo com a vegetação circunvizinha (caracterizada pela existência de inúmeras clareiras) e conservam um microclima que os diferencia do ambiente circundante.

Nos lugares sagrados, os administradores sagrados (AS) afirmam existirem as plantas medicinais indicadas no quadro 1 :

Quadro 1. Plantas dos lugares sagrados e seus efeitos medicinais. Fonte: Elaborado com base nas informações proporcionadas pelos Administradores Sagrados.

\begin{tabular}{|l|l|l|l|l|}
\hline \multicolumn{2}{|c|}{ Plantas terapêuticas } & \multicolumn{2}{c|}{ Doenças que curam } & \multicolumn{1}{c|}{ Nome científico } \\
\hline Nome científico & \multicolumn{1}{|c|}{ Nome local } & Nome vulgar & Nome local & $\begin{array}{l}\text { Dispepsia (gastrite ou úlcera } \\
\text { gástrica) }\end{array}$ \\
\hline Allophylus africanus & \multirow{2}{*}{ Nhamatubo } & Dores estomacais & Nhoca ya pha ntchombo & Cólica abdominal \\
\cline { 3 - 5 } & & Cólicas & Nhoca ya zoni & Sífilis \\
\hline Cladestermon kirikii & \multirow{2}{*}{ Munhongororo } & Venéreas & Ndenda za mabhonde & $\begin{array}{l}\text { Dispepsia (gastrite ou úlcera } \\
\text { gástrica) }\end{array}$ \\
\cline { 3 - 5 } & Dores estomacais & Nhoca ya pha ntchombo & $\begin{array}{l}\text { Conjunto de doenças tais } \\
\text { como artrites, mialgias, } \\
\text { neurites }\end{array}$ \\
\cline { 3 - 5 } & Reumatismo & Matamdaza & Disenteria bacilar \\
\hline
\end{tabular}




\begin{tabular}{|l|l|l|l|l|}
\hline Cleistochlamys kirikii & Munhongororo & Reumatismo & Matamdaza & $\begin{array}{l}\text { Conjunto de doenças tais } \\
\text { como artrites, mialgias, } \\
\text { neurites }\end{array}$ \\
\cline { 2 - 5 } & Combocore & Furúnculos & Phute & Furúnculo \\
\hline Excoecaria bussei & Mucombocole & Hérnia & Phudzi & Hérnia-umbilical congênita \\
\hline Strychnos spinosa & M'tumdulo & Cárie dentária & Nkungudza & Cárie dentária \\
\hline Trichilia emética & Muciquiri & Constipaçã & Nhamconhore & $\begin{array}{l}\text { Constipação nasal ou } \\
\text { obstipação }\end{array}$ \\
\hline
\end{tabular}

O uso de plantas medicinais, encontradas nos lugares sagrados, por comunidades constitui uma prática secular com ensinamentos valiosos através das gerações passadas, o que garante a base do seu uso no tratamento das doenças e aliado à facilidade da sua obtenção, proximidade em relação aos pacientes e, eficiência na prevenção e no tratamento das doenças, sem perigar o paciente, conforme defendem os administradores sagrados entrevistados.

\section{Produção alimentar e renda}

A Serra da Gorongosa compreende as terras que se estendem do sopé ao cume. Nesta, à semelhança de outras regiões, as terras para o cultivo são adquiridas por herança aos seus antepassados e outras por atribuição pelas lideranças tradicionais, particularmente para os que lá se estabeleceram após o término do 10 conflito armado.

De acordo com os dados colhidos no trabalho de campo as comunidades locais vivem essencialmente da exploração dos recursos pedológicos para a prática de atividade agrícola, hídricos para o consumo doméstico, florestais para o aproveitamento de ramos secos como biomassa e estacas para a construção de habitações e, faunísticos (animais de pequeno porte) para a melhoria de dieta alimentar.

A atividade agrícola consiste em duas épocas. A primeira a de preparação dos campos de cultivo, que abrange os meses de Agosto e Setembro e, segunda a de sementeira e colheita, que compreende os meses de Outubro e Novembro. É tipicamente feita em condições de sequeira e as famílias possuem, em média, uma a duas machambas ${ }^{11}$ nas margens dos rios ou em áreas depressionárias e três a quatro machambas em zonas altas. Em média, por família, contabilizamos 5 machambas, sensivelmente de 1 a 2 hectares nas zonas baixas e de 2 a 3 hectares, nas zonas altas.

As técnicas agrícolas, da maioria dos habitantes, são rudimentares e associadas ao cultivo rotativo que conservam e renovam a capacidade produtiva dos solos. As principais culturas são Zea mays (milho), Sorghum

\footnotetext{
${ }^{11}$ Refere-se a campos de cultivo.
} 
vulgare (mapira), Pennisetum tyhoides (mexoeira), Manihot esculenta Crantz (mandioca) e Vigna unguiculata (feijões nhemba), Phaseolus vulgaris (feijão manteriga), Cucurbita muchata (abóbora) e Mussa banana (banana) produzidas nos enclaves dos planaltos, na região planáltica e na peneplanície.

Nos aluviais, com elevado teor de humidade de solo e de nutrientes, produz-se Brassica aleracea var. acephala (couve), Brassica oleracea var. capitata (repolho), Allium cepa (cebola) e Allium sativum (alho).

O homem envolve-se integralmente na promoção da economia da sua família e assume atitude deliberativa na colheita e na acumulação da riqueza. Quando o lucro resultante da venda dos produtos agrícolas se avoluma, tende a abandonar o trabalho de campo para abrir bancas e quiosques (comercialização informal de produtos alimentares industriais, bebidas e roupa usada - vulgo calamidade) deixando os campos agrícolas à responsabilidade plena de sua (s) esposa (s).

[...] meu marido abriu uma banca para vender roupa de calamidade. O valor para investir na banca resultou dos rendimentos agrícolas. Porém, não tem sido fácil manter a banca porque existem muitas pessoas exercendo a mesma atividade, se não fossem os rendimentos das machambas, acho que meu marido teria abandonado a banca $\left[\mathrm{EMC}_{2}\right]$.

O trabalho assalariado, nas quintas dos privados e nos centros urbanos, parece não constituir prioridade para os membros destas comunidades, recorrendo-se a ele quando lhes confere prestígio ou não implique ausência prolongada.

[...] Eu não posso ir trabalhar para alguém e receber pouco dinheiro que nem vai chegar para alimentar minha família. A machamba me dá o suficiente para comer com minha família, sem muitos problemas. Comida tem,... bebida tem, mas quê?... me diz?... [EMC 4 ].

[...] conheço pessoas que foram viver na cidade e dizem que não arranjam trabalho e as mulheres deles estão a passar mal aqui. Outros só vem aqui nos gingar com celular e roupa bonita. Vem no fim do ano ficam aqui dois dias e vão se embora, mas a família deles fica na mesma, nem parece que têm familiares a trabalharem na cidade $\left[\mathrm{EMC}_{1,3,8}\right]$.

Este posicionamento é justificado pelo fato do homem dedicar-se permanentemente à assistência do seu agregado familiar e possibilitar-lhe um rendimento que supera cerca de 3.000,00 MT/mês (o equivalente a 50 USD), salário médio pago aos trabalhadores assalariados nas quintas, sem implicar a sua ausência da família, ao mesmo tempo que ganha consciência que as pessoas que buscam trabalho assalariado nos centros urbanos e em outras paragens não são a razão da prosperidade familiar, senão de pequenas lembranças que Ihes trazem quando regressam.

Existem outras atividades socioeconômicas exercidas particularmente pelos vindouros, nomeadamente a exploração de ouro, junto dos cursos naturais de água, pelos mineradores artesanais de ouro, atividade 
agrícola em quintas pelos pequenos produtores agrícolas, exploração madeireira pelos operadores florestais e exploração faunística pelos caçadores furtivos para fins comerciais.

\section{Serra da Gorongosa: De terras comunitárias para a Área de Conservação Total}

A criação de área de conservação reveste-se de importância singular para a "conservação territorial" ou simplesmente "geoconservação". A área de conservação destina-se a preservar a geodiversidade, o que expõe uma lógica territorial de ocupação, em que o poder público interfere, resguardando legalmente áreas sobre as quais não pode fiscalizar plenamente, deixando-as vulneráveis a vários tipos de agressão (Giudice, 2013).

O Governo de Moçambique criou a Área de Conservação Total, na Serra da Gorongosa, através do Decreto no 78/2010, de 31 de Dezembro, com a expansão dos limites do PNG para a Serra, tendo a repartido em duas categorias, designadamente:

a) Área de Conservação, localizada acima da curva de nível de 700 metros até ao cume, destinada à preservação dos ecossistemas e espécies sem intervenções de extração dos recursos, admitindo-se apenas a exploração indireta dos recursos naturais com as exceções previstas no Plano de Maneio ${ }^{12}$. O Plano de Maneio constitui um instrumento de gestão das áreas de conservação que estabelece o ordenamento e as normas que presidem a exploração e o manejo dos recursos naturais, incluindo a implantação das infraestruturas necessárias à gestão da área de conservação.

b) Zona Tampão, situada abaixo da curva de nível de 700 metros até ao sopé, porção territorial delimitada em redor da área de conservação, formando uma faixa de transição entre área de conservação e área de uso múltiplo com o objetivo de controlar e reduzir os impactos decorrentes das atividades incompatíveis com a conservação da biodiversidade, tanto do dentro para fora como de fora para dentro da área de conservação ${ }^{13}$.

A repartição geográfica da Área de Conservação Total, na Serra da Gorongosa, é ilustrada pela figura 4.

\footnotetext{
12 Ponto 4, do Artigo 13 da Lei no 16/2014, de 20 de Junho, Lei de Protecção, Conservação e Uso Sustentável da Diversidade Biológica.
} 13 Ponto 1, do artigo 40 da Lei no 16/2014, de 20 de Junho, Lei de Protecção, Conservação e Uso Sustentável da Diversidade Biológica. 
Figura 4. Repartição geográfica da Área de Conservação Total da Serra da Gorongosa Fonte: Elaborado pelo autor a partir da

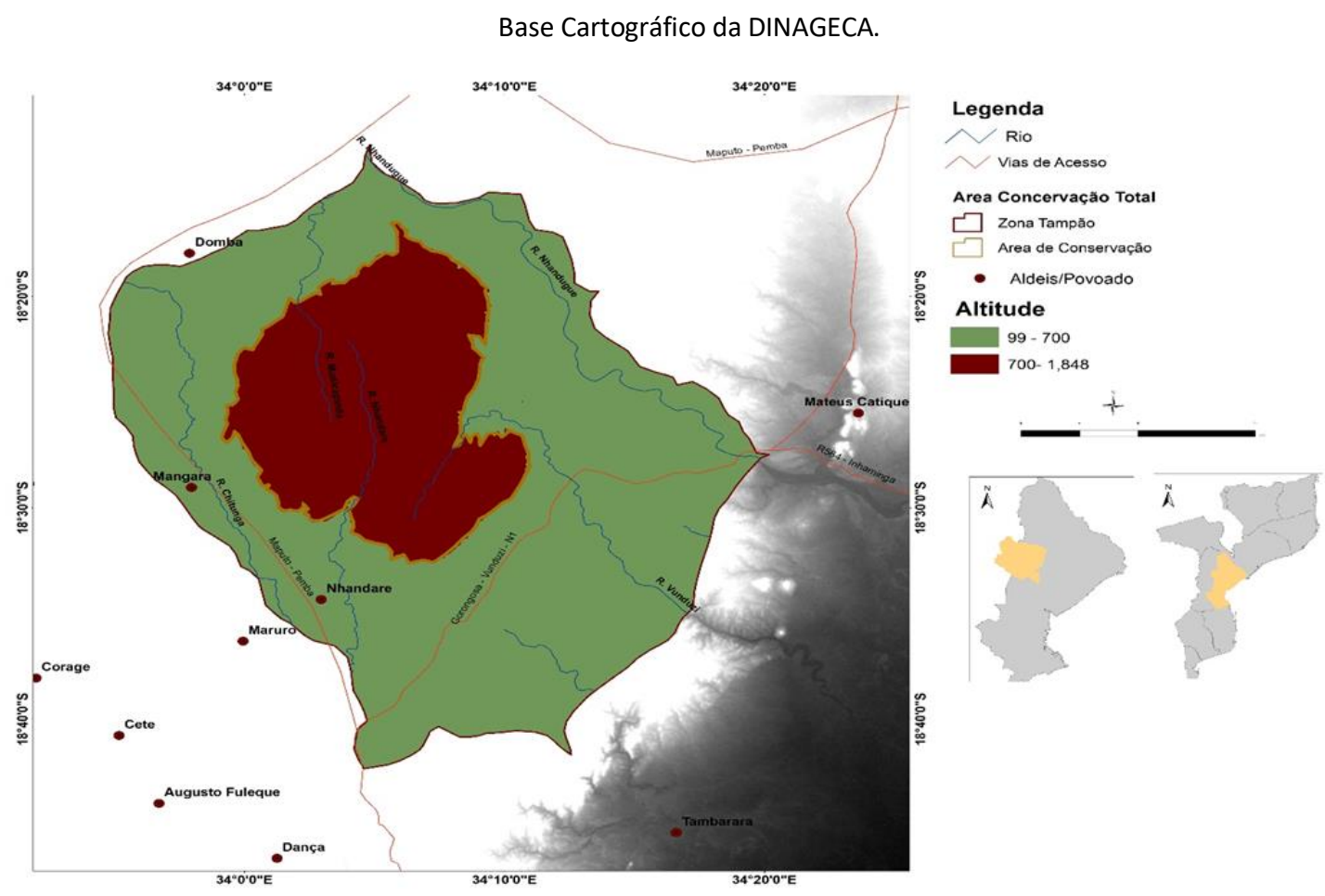

\section{Área de Conservação}

Na Área de Conservação da biodiversidade, com $367 \mathrm{~km}^{2}$ de superfície, temos o predomínio de montanhas cobertas por florestas de montanha e de biombo, que constituem o habitat extremamente importante para a diversidade de ordem animal. Nela identificamos os afloramentos de maciços rochosos intrusivos formados por granitos e garbo, que emergem da plataforma planáltica (a partir da cota média de $400 \mathrm{~m}$ ) ao complexo granito-gnáissico-magmático com afloramentos de rochas extrusivas representadas por fonólitos e traquitos, tendo o seu ponto mais alto, o pico Gogogo com 1863 metros.

O barlavento da Serra da Gorongosa, que coincide com a sua parte oriental, é influenciado pela direção do vento - predominantemente do quadrante leste - o qual arrasta consigo as massas de ar húmidas ao encontro do maciço montanhoso, configurando-se em chuvas orográficas. Neste, identificamos rios com maior desenvolvimento da rede hidrográfica, entre eles o Nhandare que escoam as águas dos cursos naturais que se situam na parte setentrional e oriental da Serra em direção ao sopé, na sua parte meridional, deixando suas águas se misturarem com as dos rios Vunduzi, Mudjicapinda e Nhandungue, sendo que este último corre na extensa região planáltica.

No sotavento, parte ocidental da Serra, assistimos o antítese, isto é, rios pouco desenvolvidos representados pelo rio Chitunga que, após receberem a contribuição de maior parte dos riachos à ocidente da 
Serra e também as águas do rio Nhandare, despejam-nas no rio Vunduzi. Destacamos ainda, os rios Mucurumadzi, Mepuaze e Sungue ${ }^{14}$ que correm em direção ao sopé sulcando os declives, deixando-se cobrir pela floresta de galeria e formando quedas de água nas vertentes, quando o desnível de terreno é acentuado, entre as curvas de nível de 800 e 1000 metros, como são os casos de cascatas de Morombodzi e de Nhamu, com mais de 100 metros de altura. Os rios Vunduzi, Nhandungue, Mucodza, Mepuaze, e Zaracambe ${ }^{15}$ nascem na Serra da Gorongosa e despejam suas águas no Lago Urema, no interior do PNG, conforme figura 5:

Figura 5. Rede hidrográfica da Serra da Gorongosa Fonte: Elaborado pelo autor a partir da Base Cartográfica da DINAGECA.

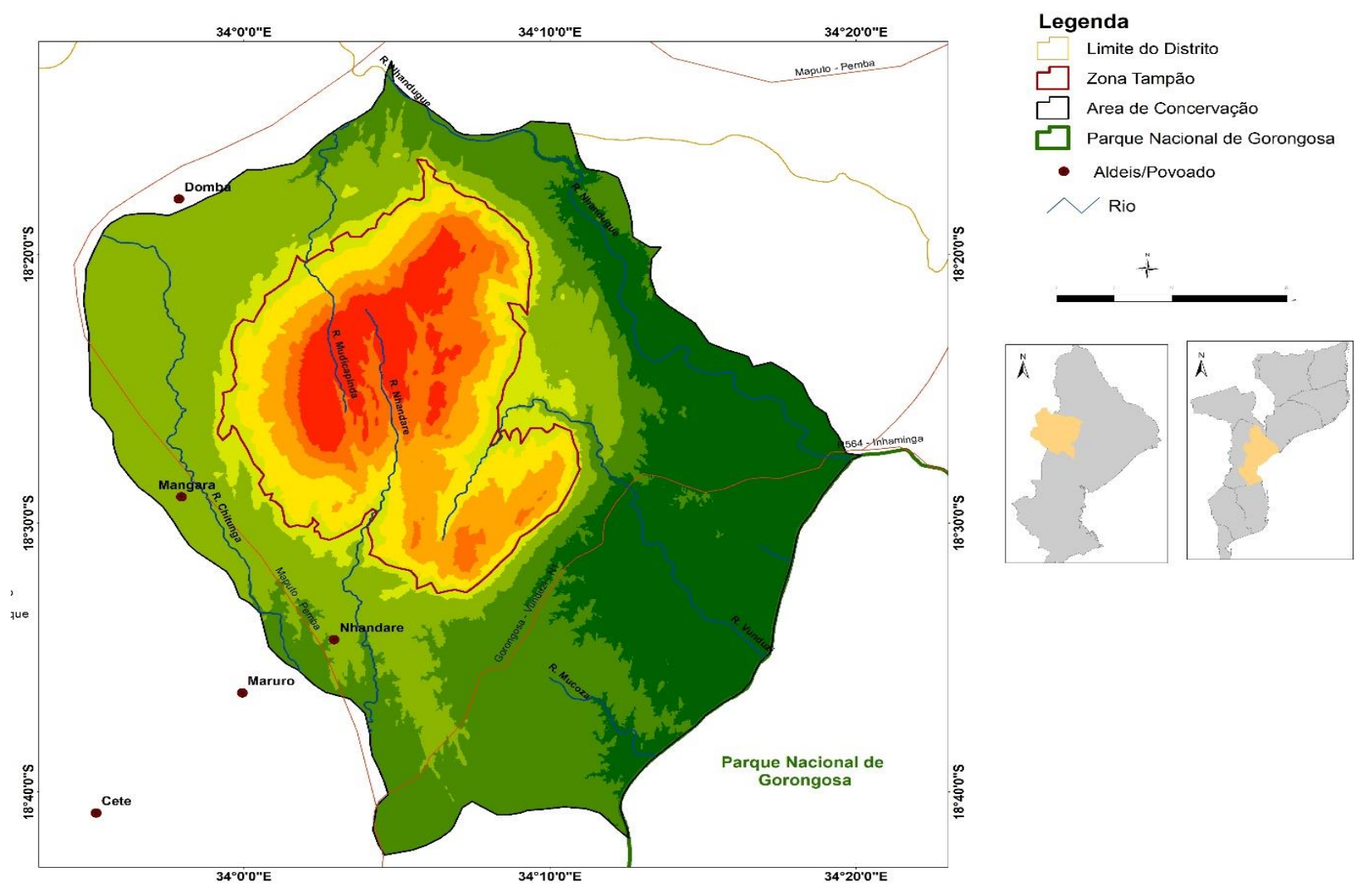

O Lago Urema é o ponto de convergência das águas da rede de drenagem que intercepta o vale, incluindo o próprio rio Urema que o alimenta, em ano de cheias excepcionais, sendo o excesso drenado para o rio Púnguè (Mafalacusser e Marques, 2000).

\footnotetext{
${ }^{14}$ Os últimos dois rios não estão representados no mapa 3, dada a pequinez da sua escala.

15 Os últimos dois rios não estão representados no mapa 3 , dada a pequinez da sua escala.
} 
A rede hidrográfica da Serra para além de assegurar a manutenção da diversidade biológica cumpre também a função de proporcionar uma expressiva quantidade e qualidade da água para o abastecimento direto às comunidades locais.

As elevadas precipitações decorrentes das chuvas orográficas favorecem o desenvolvimento de florestas tropicais com diversidade de espécies de árvores. A sua distribuição espacial reflete o padrão da unidade fisiográfica. Assim, há o predomínio da floresta hidrófila sempre verde (figura 6), que cobre os afloramentos rochosos intrusivos formados por granitos e garbo, que emergem da plataforma planáltica e assentam no complexo granito-gnáissico-magmático.

Figura 6. Cobertura vegetal da Serra da Gorongosa Fonte: Elaborado pelo autor a partir da Base Cartográfica da DINAGECA.

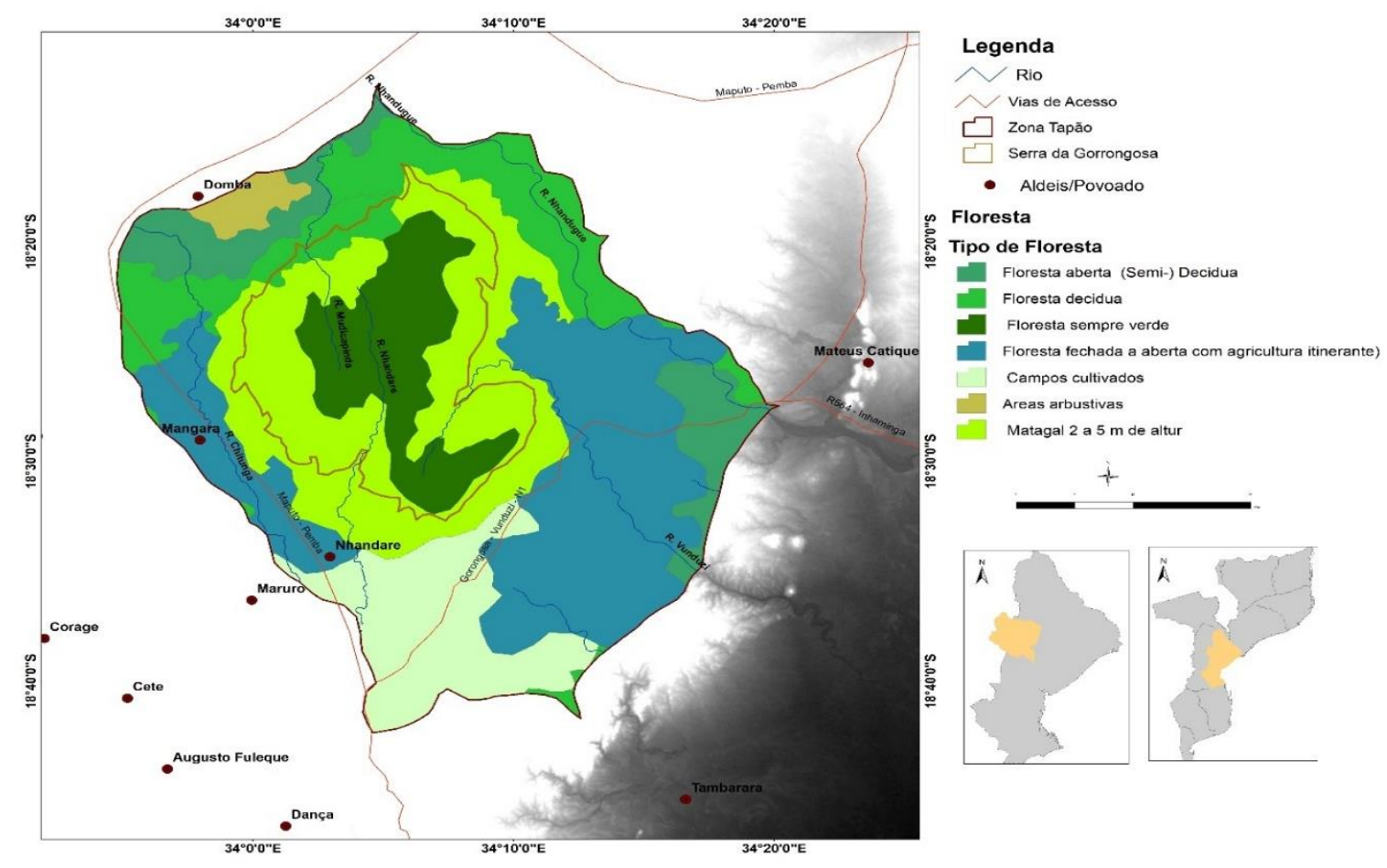

Nestas florestas visualizamos as seguintes espécies: Aphloia theiformis (Mussicate), Hypericum revolutum (Runvum), Myrsine africana (Vuzmane), Macaranga capensis (Mufucuchamacaia), Nuxia congesta (Nhamatuzu), Rapanea melanophloeos (Chmibango) (Domingos, 2011).

Na savana arbustiva, que coloniza o cume do maciço montanhoso de afloramentos de rochas extrusivas representadas por fonólitos e traquitos, destacamos as espécies de erva como Panicum esklonii, Koeleria 
capensis, P. Inequilatrum, Festuca costata, entre outras que evoluem em solos líticos, sendo estes essencialmente solos rasos com contato lítico dentro de $50 \mathrm{~cm}$, ou seja, solos pouco evoluídos. (IBID)

\section{Zona Tampão}

A Zona Tampão ou de amortecimento tem o predomínio de planaltos e de superfície aplainada interrompida por inselbergs de dimensões e alturas variáveis de rochas esfoliadas, deixando-se cercear por peneplanície de aluviões e por "Graben" de Urema, limitando o planalto da Gorongosa a ocidente e o de Cheringoma a oriente, com uma extensão de cerca de $200 \mathrm{~km}$ de comprimento e $40 \mathrm{~km}$ de largura, de acordo com Mafalacusser e Marques (2000).

A peneplanície de aluviões ou de acumulação estende-se até o limite Norte da Área de Conservação do PNG, descansando na Zona Tampão que é a comum para ambas áreas de conservação descontínuas. Esta caracteriza-se pela "grande uniformidade do seu relevo, com declives suaves e cumes aplanados cujas cotas variam entre os 300 e os $600 \mathrm{~m}$, embora aquelas, a oeste da Serra sejam superiores às da região Este, resultando num talude de inclinação no sentido W-E ou NW-E" (MAFALACUSSER e MARQUES, 2000, p. 8).

O vale, de acordo com Ferro e Bouman (1987), poderá ser produto de falhas geológicas que terão ocorrido no decurso do Cretácico e seguidamente no Mioceno, limitando o grande vale do Urema, onde depósitos de Cretácico marinho e do Terciário poderão estar soterrados por aluviões.

Na região planáltica encontramos, por difusão, as florestas de montanha e de biombo e o estrato graminoso com ervas bem desenvolvidas, representados pelo matagal com 2 a 5 metros de altitude que se difunde para a Zona Tampão particularmente a Este, Sul e Oeste da Serra, contendo espécies Andropogon gayanus (Inhamangaia), Heteropogon cymbaria (Tsekera), Hyperthelia dissoluta (Bundo), Hyparrhenia filipendula (Buio), etc. (Domingos, 2011, p. 7).

A floresta de miombo fornece alimento e abrigo a mamíferos como Kobus elliprymnus (antílopes), Oryctolangus cuniculos (coelhos), Potamochoerus porcus (porco bravo), Hystrix afriacae-australis (porco espinho), Vivera civeta (Civeta), Thryonomys swinderiaaanus (rato das canas), Cercopithecus pygerytrus (macaco simango) e diferentes espécies de répteis e aves.

Na peneplanície reconhece-se as florestas fechada e aberta com a agricultura itinerante (Este e a Oeste) e campos cultivados a Sul que evoluem em solos castanhos de textura arenosa, os quais alternam com solos vermelhos de textura média à oriente (figura 7): 
Figura 7. Solos da Serra da Gorongosa Fonte: Elaborado pelo autor a partir da Base Cartográfica da DINAGECA.

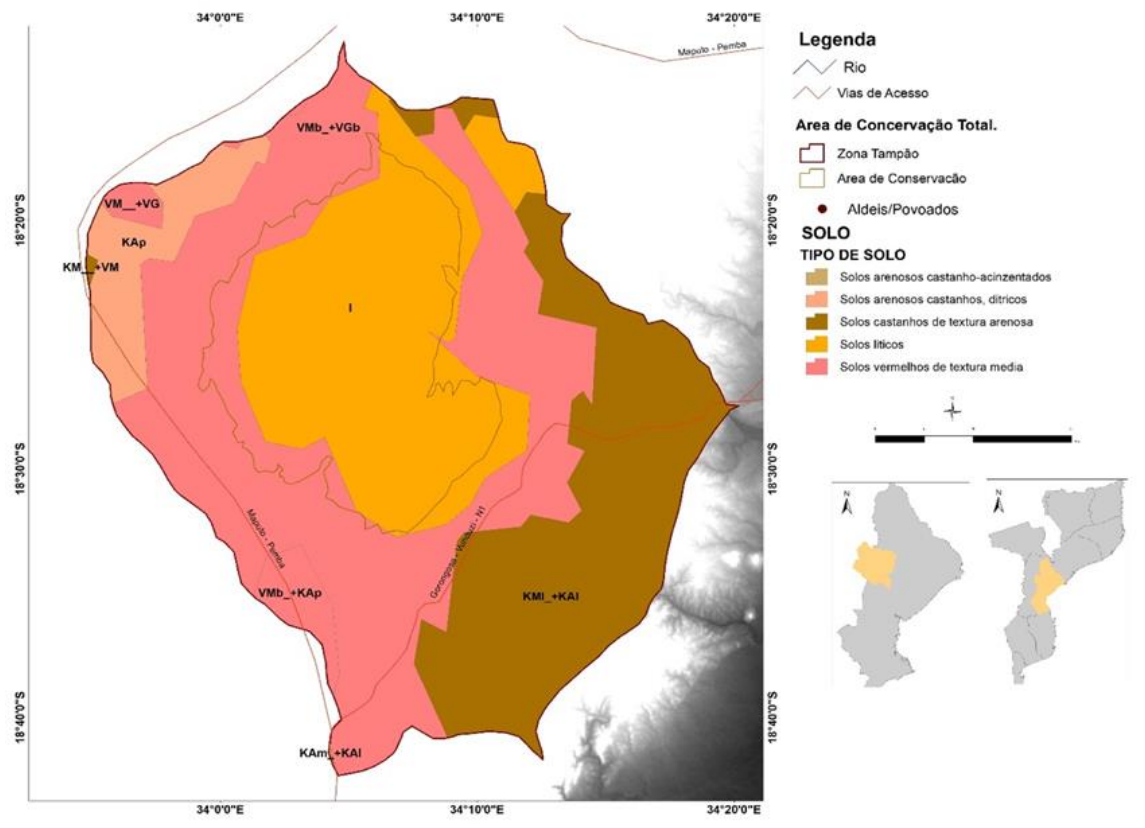

Nestes solos encontramos savanas de Acacia, Sclerocarya, Piliostigmae, Palemeiras em solos argiloarenoso, mopane em solos holomórficos de argilas ricas e pradarias inundáveis em solos aluviares e hidromórficos mais recentes.

A Zona Tampão alberga maiores concentrações de população designadamente nos povoados de Massara, Nhaurire, Nhatsapa, Cavalo, Vunduzi, Nhantaca, Mucunambira, Nhaussembe, Mangara, Nhamanza, entre outras que se localizam fundamentalmente ao Sul e aa Este da Serra da Gorongosa. Nela é possível observarmos habitações convencionais que se diluem em edificações de construção precária.

Do ponto de vista de ciências geográficas, a criação da Área de Conservação Total na Serra da Gorongosa, claramente bem delimitada para a proteção da diversidade biológica, corresponde ao estabelecimento do território, pois a introdução dos limites afeta o comportamento dos membros das comunidades locais no acesso à área de conservação e aos recursos naturais, dado os imperativos legais.

De acordo com SACK $(1986$, p.19) "The delimitation becomes a territory only when its boundaries are used to affect behaviour by controlling access", o mesmo que, na nossa tradução, "a delimitação torna-se num território somente quando os seus limites são usados para afetar o comportamento pelo controlo do acesso [a área e aos recursos naturais]".

A criação da área de conservação tem influência negativa na vida dos diferentes atores sociais com interesses distintos, pois as novas formas de apropriação do território, das quais destacamos a expropriação 
de terras para proteção da biodiversidade e para a prática do turismo, em detrimento das práticas socioculturais e econômicas de outros atores, marcam uma nova realidade na Serra, onde as relações de poder, na nova realidade, irão gerar uma multiplicidade de territórios com territorialidade, dimensão e conteúdo específicos, a serem introduzidos pelo novo ordenamento territorial da Serra da Gorongosa, no contexto da extensão do Plano de Maneio do PNG.

\section{Sobreposições territoriais da área de Conservação Total}

A criação da Área de Conservação Total recaiu sobre as terras do domínio das comunidades locais (garantidos os seus direitos territoriais pelo $E s \operatorname{sado}^{16}$ ), propriedades privadas de pequenos agricultores, áreas detentoras de licenças de prospecção mineira e de concessão florestal.

\section{Em Terras Comunitárias}

Na Serra da Gorongosa encontramos comunidades que se distribuem espacialmente pelos povoados de Nhamadzi e Mangara (Chefe) na Área de Conservação e pelos povoados de Massara, Nhaurire, Nhatsapa, Cavalo, Vunduzi, Nhantaca, Mucunambira, Nhaussembe, Mangara, Nhamanza e outras de menor expressão na Zona Tampão, como ilustra a figura 8:

Figura 8. Distribuição espacial dos povoados na Área de Conservação Total Fonte: Elaborado pelo autor a partir da Base Cartográfica da DINAGECA.

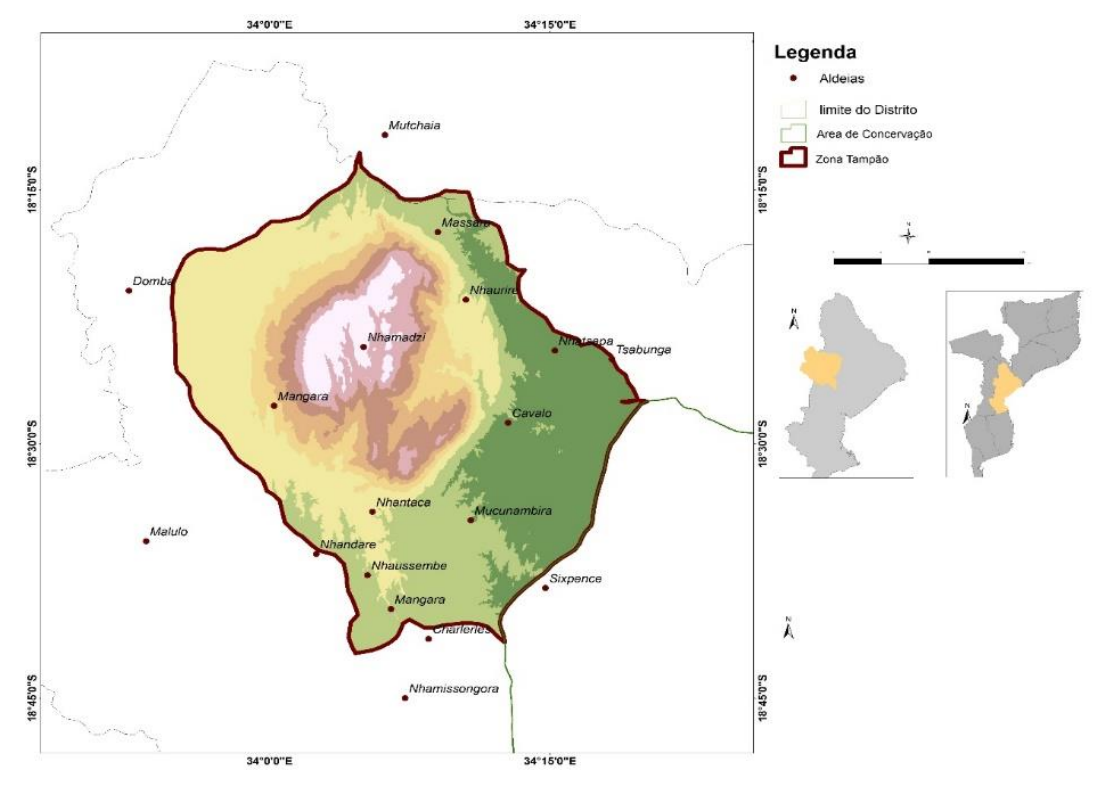

\footnotetext{
${ }^{16}$ Artigo 3 da Constituição da República (2004).
} 
A sobreposição territorial da Área de Conservação Total nas terras comunitárias é percebida como o ponto de discórdia por, não entender destas comunidades, contemplar a obrigatoriedade da sua retirada da Serra e implicar restrições quanto a exploração dos recursos naturais. O Plano de Manejo do PNG (2016) estabelece que, na Serra da Gorongosa, será considerado o ordenamento territorial que admita:

[...] a presença contínua e as atividades agrícolas levadas a cabo pela população acima do contorno dos 700 metros da curva de nível, [...] desde que sejam adotadas práticas agrícolas de conservação. Contudo, dentro do complexo florestal principal, não deve haver assentamento humano nem prática de agricultura (PM, 2016, p. 538).

A informação sobre a eventual retirada das comunidades dos seus locais de residência resulta, segundo estas, dos encontros promovidos pelos técnicos do PNG, em 2011, para a sua sensibilização sobre a importância do Parque na conservação da biodiversidade e no desenvolvimento da economia local.

De acordo com a aplicação do questionário aos membros das comunidades locais, $76 \%$ dos inqueridos não concordam com a atual organização territorial e começaram a reivindicar a posse das terras comunitárias, através de Comitês de Gestão dos Recursos Naturais (CGCRN), seguindo o exemplo do CGRN de Canda que procedeu a delimitação e regularização das suas terras no ano de 2000.

Entendemos por "terras comunitárias regularizadas" aquelas que passaram por todas as fases de delimitação e registo no Cadastro dos Serviços Provinciais de Geografia e Cadastro de Sofala (SPGCS). Os CGRN que, em representação das suas respectivas comunidades, requereram e delimitaram as suas respectivas terras em 2011, segundo os registos dos SPGCS, figuram no quadro 2.

Quadro 2. Terras comunitárias na Serra da Gorongosa e redondezas (2011) Fonte: Elaborado pelo autor a partir de banco de dados dos SPGCS, 2018.

\begin{tabular}{|c|c|c|c|c|c|c|}
\hline \multirow[b]{2}{*}{ Proprietário } & \multirow[b]{2}{*}{$\begin{array}{l}\text { Número } \\
\text { Processo }\end{array}$} & \multirow{2}{*}{$\begin{array}{l}\text { Ano de } \\
\text { Registo }\end{array}$} & \multirow[b]{2}{*}{$\begin{array}{l}\text { Superfície } \\
\text { (Ha) }\end{array}$} & \multicolumn{2}{|l|}{ Localização } & \multirow[t]{2}{*}{ Situação } \\
\hline & & & & $\begin{array}{l}\text { Posto } \\
\text { Administrativo }\end{array}$ & Localidade & \\
\hline CGRN & 2398 & 2011 & $155.387,61$ & Gorongosa & Vunduzi & Em tramitação \\
\hline CGRN & 2405 & 2011 & 94.375 .08 & Gorongosa & Vunduzi & Em tramitação \\
\hline
\end{tabular}

As terras comunitárias requeridas e delimitadas em 2011 ainda não foram objeto de atribuição das Certidões Oficiosas ${ }^{17}(\mathrm{CO})$ às respectivas comunidades através dos CGRN, por se ter constatado que estas evoluem no interior da Área de Conservação Total da Serra da Gorongosa.

\footnotetext{
17 O equivalente ao Documento de Uso e Aproveitamento de Terra (DUAT), mas atribuível às terras comunitárias.
} 
A situação anteriormente mencionada, é análoga ao das comunidades residentes em terras limítrofes dos distritos que confinam o PNG, nomeadamente Dondo, Cheringoma, Gorongosa, Nhamatanda e Muanza, conforme elucida o quadro 3.

Quadro 3. Terras comunitárias das comunidades residentes nas imediações do PNG (2011) Fonte: Elaborado pelo autor a partir de banco de dados dos SPGCS, 2018.

\begin{tabular}{|c|c|c|c|c|c|c|}
\hline \multirow[b]{2}{*}{ Proprietário } & \multirow{2}{*}{$\begin{array}{l}\text { Número } \\
\text { Processo }\end{array}$} & \multirow{2}{*}{$\begin{array}{l}\text { Ano de } \\
\text { Registo }\end{array}$} & \multirow{2}{*}{$\begin{array}{l}\text { Superfície } \\
\text { (Ha) }\end{array}$} & \multicolumn{2}{|l|}{ Localização } & \multirow[b]{2}{*}{ Situação } \\
\hline & & & & $\begin{array}{l}\text { Posto } \\
\text { Administrativo }\end{array}$ & Localidade & \\
\hline \multirow{5}{*}{ CGRN } & 2397 & \multirow{6}{*}{2011} & $36.614,8$ & Cheringoma & Mazamba & \multirow{6}{*}{$\begin{array}{l}\text { Em } \\
\text { tramitação }\end{array}$} \\
\hline & 2399 & & 23.492 & Nhamatanda & Macorococho & \\
\hline & 2406 & & $1.130,26$ & Muanza & Nhantadza & \\
\hline & 2407 & & $40.668,75$ & Cheringoma & Inhaminga & \\
\hline & 2408 & & $37.628,89$ & Nhamatanda & Nhamacolomo & \\
\hline $\begin{array}{l}\text { CGRN } \\
\text { Maguacua }\end{array}$ & 2411 & & $115.643,84$ & Dondo & Savane & \\
\hline \multicolumn{3}{|l|}{ Total } & $255.178,54$ & & & \\
\hline
\end{tabular}

A delimitação de terras comunitárias na Serra da Gorongosa reforça a legitimidade de pertença das terras às comunidades locais. A despeito da delimitação ter ocorrido após a criação da Área da Conservação Total (Dezembro de 2010), deve-se frisar que as comunidades nativas estabeleceram-se na Serra da Gorongosa, nos princípios do século XIX, portanto, muito antes da extensão dos limites do PNG para a Serra. A figura 9, ilustra a sobreposição da Área de Conservação Total em terras comunitárias, na Serra da Gorongosa.

Figura 9. Sobreposição da Área de Conservação Total nas Terras Comunitárias. Fonte: Elaborado pelo autor a partir da Base Cartográfica da DINAGECA.

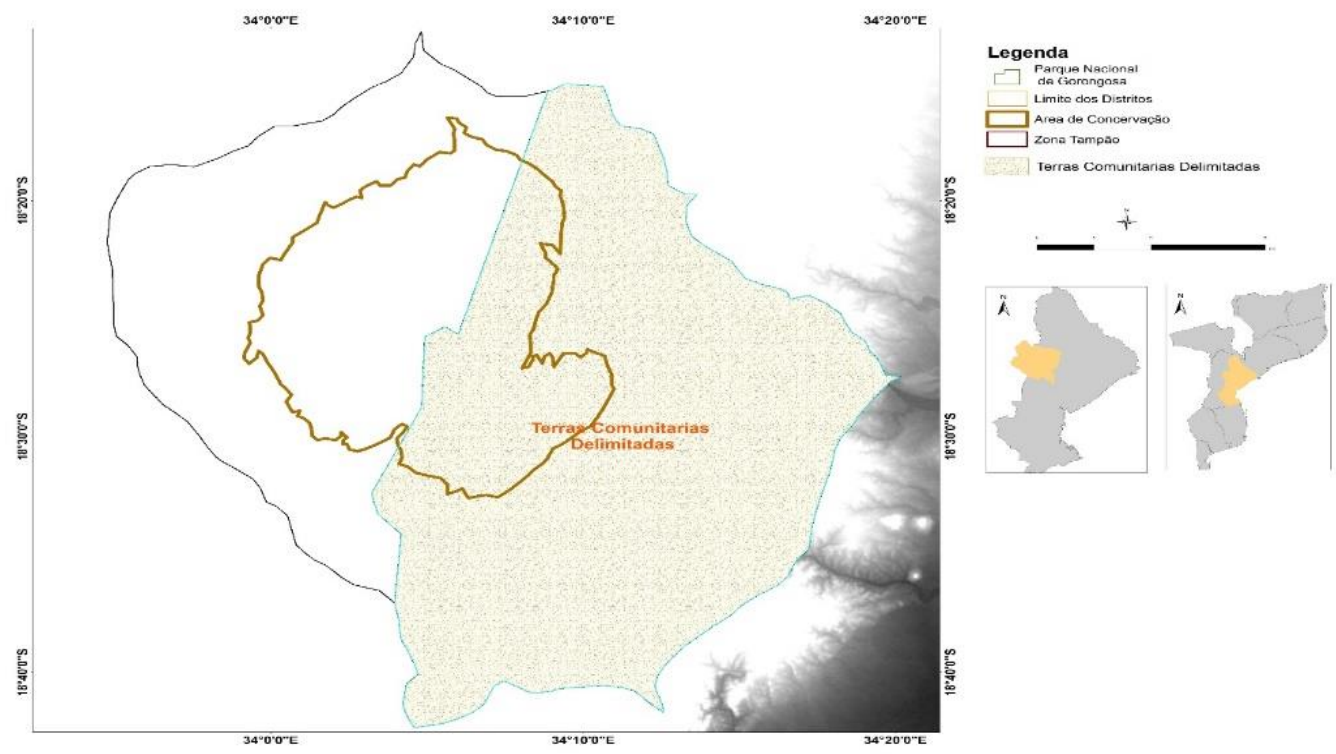


As terras comunitárias, que integram potencialmente os lugares sagrados, ocupam pouco mais de metade da Área de Conservação Total e estendem-se para Sul, Este e Nordeste desta, cobrindo os Postos Administrativos de Nhamadzi, Gorongosa e Vunduzi.

Em propriedades privadas de pequenos agricultores

Identificamos, particularmente na parte ocidental e no Sul da Área de Conservação, propriedades privadas de pequenos agricultores licenciadas e que se concentram maioritariamente na Zona Tampão. A figura 10 apresenta esta situação de sobreposição territorial.

Figura 10. Sobreposição da Área de Conservação Total nas parcelas de terras detentoras de DUAT. Fonte: Elaborado pelo autor a partir da Base Cartográfica da DINAGECA.

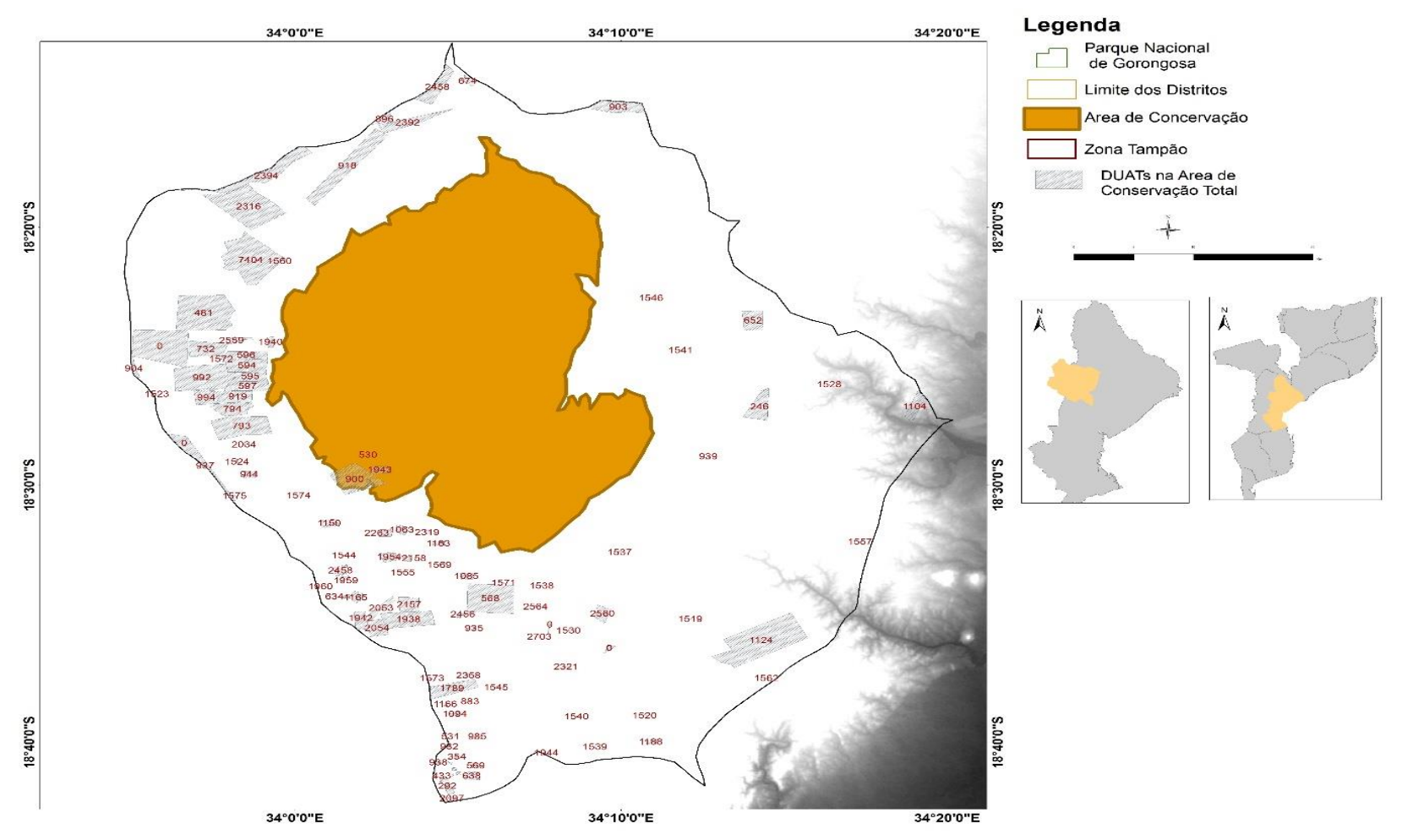

Foram identificadas 37 atribuições de parcelas de terra (10 a 1.000 ha) aos privados, feitas pelo Governo Provincial de Sofala através dos SPGCS, para fins agrícolas, com maior incidência de 2003 a 2008, como ilustra o quadro 4. 
Quadro 4. Número de propriedades privadas de terra na Serra da Gorongosa (2003-2008). Fonte: Elaborado a partir de base de dados disponibilizados pelos SPGCS.

\begin{tabular}{|l|l|l|l|}
\hline $\mathrm{N} / 0$ & Localidade & Comunidades & Número de Processos \\
\hline 01 & Nhamadzi & Canda & 31 \\
\hline 02 & \multirow{3}{*}{ Vunduzi } & Nhancuco & 1 \\
\cline { 3 - 4 } & & Murombodzi & 2 \\
\cline { 3 - 4 } & & Nhambirira & 3 \\
\hline 04 & & 37 \\
\hline \multicolumn{2}{|l}{} \\
\cline { 3 - 4 }
\end{tabular}

O maior número das atribuições de parcelas de terra recai sobre a comunidade de Canda, na localidade de Nhamazi $(83,7 \%)$, em virtude de usufruir terras bastante férteis para a prática agrícola. Em outras comunidades as atribuições são relativamente diminutas.

Em áreas de prospecção mineira

A Área de Conservação Total da Serra da Gorongosa é, na sua totalidade, coberta por 9 licenças de prospeç̧ão mineira de ouro. Segundo DONDEYNE, et. al. (2007), entre os anos 2003 e 2006 a empresa Finlandesa "GTK consortium" procedeu ao levantamento dos recursos minerais na zona centro e em 2005 a "J.F. Mining" manifestou interesse para investir no jazigo de ouro em Tsiquiri. A figura 11 apresenta a sobreposição da Área de Conservação Total com áreas de prospecção mineira:

Figura 11. Sobreposição da Área de Conservação Total nas áreas de prospecção mineira. Fonte: Elaborado pelo autor a partir da Base Cartográfica da DINAGECA.

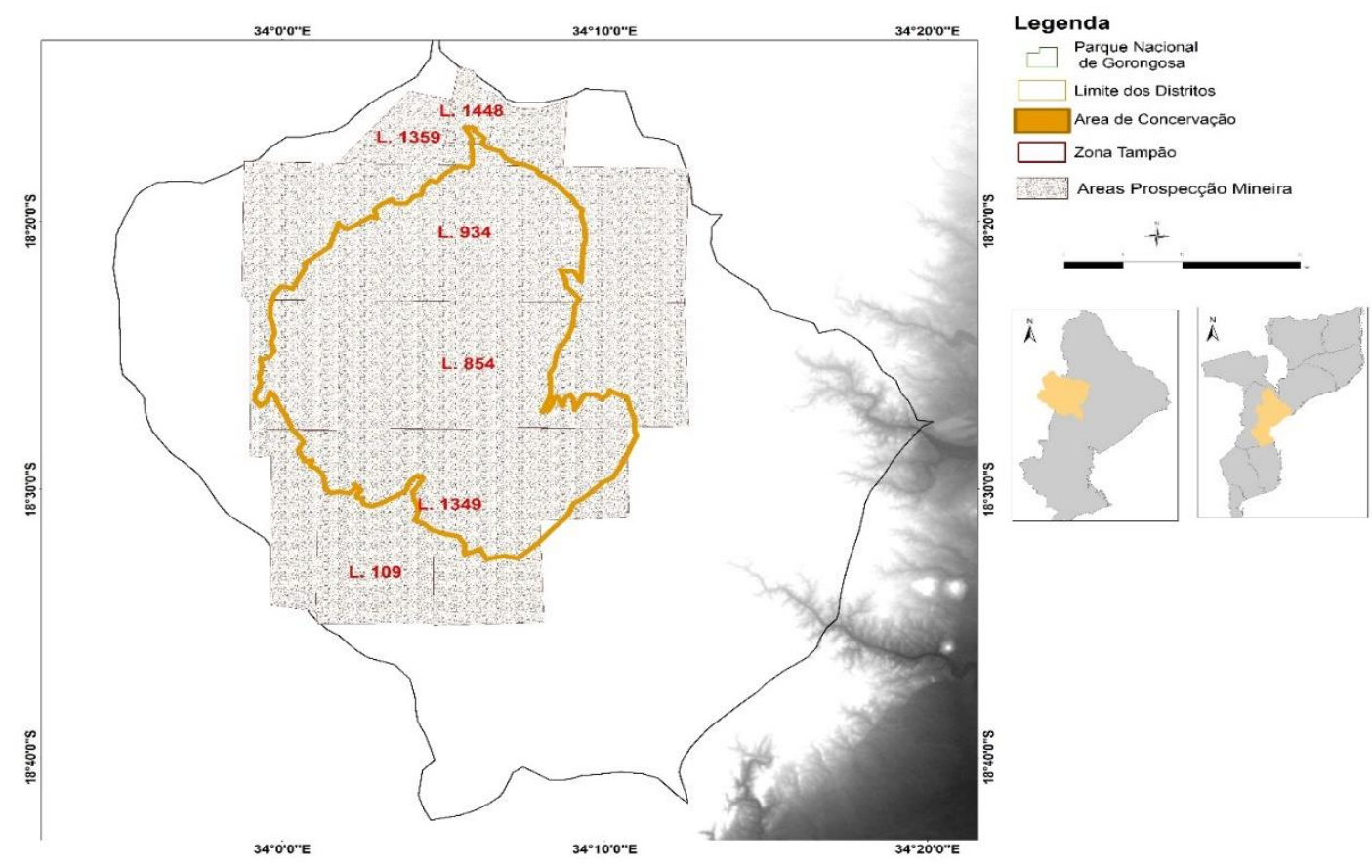


As licenças das propriedades indicadas na figura 9, foram atribuídas entre os anos 2001 e 2005, por um período sensivelmente de 5 anos e canceladas ou abandonadas sucessivamente até finais de 2009. Deste ano até 2017 as atribuições foram condicionadas pela perspectiva da conversão da Serra em Área de Conservação Total e pelos conflitos armados que se sucederam (2013-2016).

O cancelamento das licenças esteve, segundo os técnicos da Direção Provincial dos Recursos Minerais e Energia, na razão da insegurança para levar a cabo a atividade de prospecção mineira, falta de capacidade financeira pelos detentores das licenças para o desenvolvimento da atividade e conversão da Serra em Área de Proteção Total.

Houve, no entanto, novas concessões de licenças de prospecção mineira, cujas atribuições restringiramse particularmente na Zona Tampão, particularmente de 2012 a 2014. No quadro 6, apresentamos a relação das licenças, superfície e, data de concessão e de validade das licenças.

Quadro 6: Dados sobre as licenças de concessão para a exploração mineira (2012-2014) Fonte: Trimble, Landfolio Cadastro Mineiro de Moçambique.

\begin{tabular}{|c|c|c|c|c|c|c|}
\hline \multirow[t]{2}{*}{$\mathrm{N} / \mathrm{O}$} & \multirow{2}{*}{$\begin{array}{c}\text { № } \\
\text { Licença }\end{array}$} & \multirow[t]{2}{*}{ Interesse } & \multicolumn{2}{|c|}{ Data de } & \multirow{2}{*}{$\begin{array}{l}\text { Superfície } \\
(\mathrm{Ha})\end{array}$} & \multirow[t]{2}{*}{ Referência Geográfica } \\
\hline & & & Concessão & Validade & & \\
\hline 01 & 4326 & \multirow{3}{*}{ Pessoa coletiva } & $16 / 04 / 2012$ & $16 / 04 / 2017$ & $8.652,39$ & Nhamadzi, Vunduzi \\
\hline 02 & 4997 & & 07/11/2012 & $07 / 11 / 2037$ & 81,11 & Gorongosa \\
\hline 03 & 7006 & & $10 / 09 / 2014$ & $10 / 09 / 2039$ & $1.440,42$ & Nhamadzi \\
\hline 04 & 7295 & Pessoa singular & $19 / 12 / 2014$ & $19 / 12 / 2024$ & 20,28 & Nhamadzi \\
\hline \multicolumn{5}{|c|}{ Total } & 10.194,2 & \\
\hline
\end{tabular}

A exploração artesanal de ouro, sem atribuição de licença, tem constituído uma atividade de destaque na Área de Conservação Total. A informação sobre a exploração artesanal passou a ser largamente difundida a partir do ano de 2003, altura em que os camponeses de Tsiquire descobriram e exploraram ouro, o que teria concorrido para atrair centenas de exploradores artesanais, especificamente os da província de Manica, detentores de inegável experiência nesta atividade.

A exploração viria, a partir de 2005, a expandir-se para os rios Mucoza, Cudze, Vunduzi-Púnguè (Associação Takarica) e Nhandungue, estando associada aos filões de quartzito e depósitos aluvionais. 
Em áreas de concessão florestal

A Sudeste e Nordeste, a Área de Conservação Total da Serra da Gorongosa é confinada por concessões florestas, em uma faixa que se estreita para o Norte, no interior da Zona Tampão, a partir de uma base relativamente larga à Sudeste da Serra. As concessões florestais ocupam uma superfície de cerca de $300 \mathrm{~km}^{2}$, no interior da Área de Conservação Total.

As atribuições das licenças de exploração madeireira pelos Serviços Provinciais de Floresta e Fauna Bravia de Sofala (SPFFBS) aos detentores Zeca Morgado, SOFLORA e EDE, distam da década de 80 e foram concedidas abaixo da curva de nível de 500 metros.

A gestão das áreas de concessão florestal é realizada mediante o Plano de Maneio Florestal (PMF). O PMF apresenta os volumes e espécies florestais a serem explorados anualmente, contempla as ações de reflorestamento em áreas desnudadas, apresenta as operações silviculturas, declara o diâmetro mínimo admissível de corte e distribuição diamétrica das espécies comerciais, indica as formas de maneio de produtos florestais não madeireiros (particularmente a fauna) e procede o zoneamento da concessão florestal.

A área coberta pelas concessões florestais apresenta predominantemente uma vegetação de miombo de baixa a média altitude, que inclui florestas abertas e fechadas, com espécies florestais, de grande valor comercial, tais como Brachystegia spiciformis (Messassa), Julbernardia globiflora (Muimbe), Pterocarpus angolensis (Umbila) e Combretum imberbe (Mondzo) - ver figura 10.

Figura 2:Sobreposição da Área de Conservação Total nas áreas de concessões florestais Fonte: Elaborado pelo autor a partir da Base Cartográfica da DINAGECA

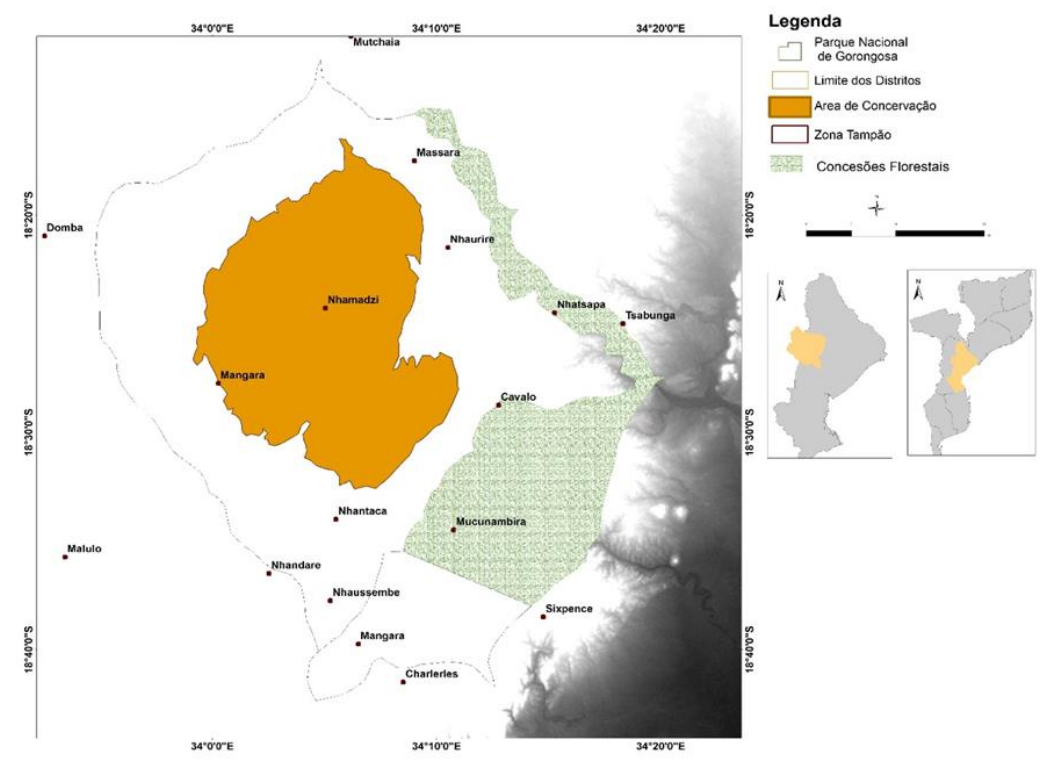


O quadro 7 sistematiza as sobreposições territoriais da Área de Conservação Total da Serra da Gorongosa em terras comunitárias, parcelas de terras privadas licenciadas e, áreas de prospecção mineira e de concessão florestal.

Quadro 7: Índice percentual da sobreposição territorial da Área de Conservação Total com as diferentes formas de ocupação da terra Fonte: Elaborado pelo autor a partir dos dados fornecidos pelos SPGCS.

\begin{tabular}{|c|c|c|c|c|}
\hline \multirow{2}{*}{ /O } & \multirow{2}{*}{$\begin{array}{l}\text { Sobreposição da Área de } \\
\text { Conservação Total (SG) com: }\end{array}$} & Superfície Coberta & \multirow{2}{*}{$\begin{array}{l}\text { Sobreposição da Área de Conservação } \\
\text { com: }\end{array}$} & Superfície Coberta \\
\hline & & $\%$ & & $\%$ \\
\hline 1 & Parcelas de Terras Privadas & 4 & Parcelas de Terras Privadas & 1 \\
\hline 2 & Terras Comunitárias & 62 & Terras Comunitárias & 44 \\
\hline 3 & Áreas de Prospecção Mineira & 1 & Áreas de Prospecção Mineira & --- \\
\hline 4 & Concessão Florestal & 27 & Concessão Floresta & --- \\
\hline
\end{tabular}

A sobreposição territorial da Área de Conservação Total nas Terras Comunitárias é assaz expressiva (62\%), sucedendo-se o mesmo na área de conservação (44\%). Tal realidade condiciona sobremaneira as atividades econômicas e socioculturais das comunidades locais.

As terras comunitárias, mais do que espaço físico, constituem elemento carregado de relações simbólicas importantes para a manutenção da cultura das comunidades locais. A sua territorialidade incorpora desde a dimensão subjetiva de pertencimento, que arrasta a ancestralidade e a dimensão econômica de sustentabilidade que se relaciona com a disponibilidade local de elementos ambientais necessárias para a continuidade das práticas socioculturais das comunidades. Explica-se o carácter imprescindível do reconhecimento do direito de posse às terras comunitárias historicamente ocupadas pelas comunidades locais, mesmo em situação de sobreposição territorial. 
Modelo de gestão da Área de Conservação Total na Serra da Gorongosa e discórdias

A tendência de gestão das áreas de conservação no mundo influenciou e influencia as políticas e o seu modelo de gestão em Moçambique, determinando o emergir de novas práticas. A Lei no 16/2014, de 20 de Junho (Lei de Proteção, Conservação e Uso Sustentável da Diversidade Biológica), republicada após às alterações introduzidas pela Lei no 5/2017, de 11 de Maio ${ }^{18}$ estipula a competência do órgão implementador [Ministério da Terra, Ambiente e Desenvolvimento Rural] em executar as políticas para as áreas de conservação e a garantir a participação responsável dos setores privado e das comunidades, nos processos de administração das áreas protegidas.

A despeito dos eventos internacionais terem influenciado as reformas constitucionais (1990 e 2004) e demais leis e regulamentos específicos, entendemos que o modelo de gestão das áreas de conservação em Moçambique, na prática, arrastam estratégias do modelo clássico/velho paradigma, não fugindo à regra, o modelo adotado pelo PNG.

O PNG é de gestão compartilhada ou mista entre o Governo de Moçambique (GM) e a CARR FUNDATION ${ }^{19}$, sendo esta última uma Organização Não Governamental (ONG) dos EUA que, em associação com o GM, desenvolvem esforços para a proteção e restauração dos diferentes ecossistemas e afiançam o incremento o turismo para a Serra da Gorongosa, valendo-se da extensão dos limites do Parque.

O Governo de Moçambique é legislador e supervisor da implementação das políticas ambiental para áreas de conservação e, a despeito de ter seu representante nas funções de liderança do Parque, parece-nos certo que a CARR FUNDATION é quem mobiliza maior percentagem de fundos para o investimento no PNG, mas viabilizado pelo governo. A CARR FUNDATION detém, pois, o poder financeiro e por conseguinte o poder social e político.

O modelo de gestão adoptado pelo PNG parte de princípio de que a presença humana é sempre prejudicial para a natureza e não considera os diferentes modos de vida das comunidades existentes no seu interior. A presença das comunidades, com as suas práticas de apropriação dos recursos naturais, cria para os gestores ambientais do PNG, aspectos problemáticos para a proteção da diversidade biológica. Entrevista conduzida ao Diretor da Área de Conservação (2012) consideraria que:

O Parque está extremamente preocupado com a presença das comunidades na Serra da Gorongosa, pois as práticas agrícolas desenvolvidas por estas concorrem para o desbravamento da floresta,

\footnotetext{
18 Números 2 e 3 do Artigo 6 (Órgão de Administração das Áreas de Conservação).

19 Têm um acordo assinado com Governo de Moçambique, em 2008, para restaurar e co-gerir o Parque Nacional da Gorongosa, nos próximos 20 anos. O Acordo foi estendido, no ano de 2016, por mais 25 anos, ou seja, 12 anos antes de expirar o primeiro tratado.
} 
particularmente nas vertentes das montanhas. A caça furtiva é outra questão que nos preocupa, se considerarmos que abatem os animais para sua comercialização, ao longo da EN1.

A par destas situações assiste-se a exploração artesanal do ouro, cujas técnicas de exploração passam pelo desvio dos cursos de água e incremento da turvação das águas, com consequências para o Parque.

A prática agrícola e a exploração artesanal de ouro são consideradas, pelos gestores ambientais do PNG, como sendo atividades socioeconômicas responsáveis pelas alterações significativas do regime hidrosedimentológico do Lago Urema e da morfodinâmica fluvial dos rios contribuintes do lago transmissor, o que condiciona, em certa medida, a atuação dos gestores do Parque no maneio da área de conservação. Este julgamento tem alinhamento com os resultados dos estudos realizados pelo Sweco \& Associados (2004, p.77) apud. Tinley (1977) e Burlison et. al. (1977):

\begin{abstract}
O alastramento do cultivo nas encostas deste monte [Serra da Gorongosa], o abate de árvores, as queimadas e a consequente destruição da cobertura vegetal natural são circunstâncias que continuam presentes até agora, principalmente ao longo das encostas Este e Sul, onde o cultivo está a ser praticado em declives até 45 . Estas práticas poderiam ter grandes efeitos no regime hidrológico local, levando a uma reduzida capacidade de retenção da água pelos solos, aumento de escorrência após as chuvas, e uma maior incidência de inundações-relâmpago. Contudo, não existem dados hidrológicos para o monte ou outras bacias de Urema, a Leste ou Oeste, o que torna impossível quantificar os efeitos do uso da terra no fornecimento de água ao Parque Nacional da Gorongosa. Pode-se apenas conjecturar que a expansão da prática de cultivo no monte e noutras áreas da bacia, poderá causar impactos adversos na hidrologia do Parque.
\end{abstract}

Para o Diretor para Área da Conservação, tais modificações substancias no regime hidrosedimentológico do Lago Urema e na morfodinâmica fluvial não afetam unicamente a paisagem físico-ambiental como também interferem na redução da fauna e da flora, uma vez que o lago constitui principal habitat dos organismos vivos.

Os discursos dos gestores ambientais do PNG, não consideram o espaço preservado no seu estado originário, mas sim de espaço que se encontra em estado de degradação, como atesta a meta da Estratégia de Conservação constante do Plano de Maneio (2016) que se refere a conservação da fauna bravia como estando ameaçada pela prática de agricultura realizada pelas comunidades locais, daí a necessidade de se impedir, por todas as formas, a permanência do ser humano nas áreas de conservação.

\title{
Considerações finais
}

Abordamos a sobreposição territorial da Área de Conservação Total em terras comunitárias, enfatizando as comunidades locais na Serra da Gorongosa, organização social, produção alimentar, criação de Área de Conservação Total e sua repartição geográfica. Ressaltamos, em seguida, a caracterização do meio físico e da ocupação humana na Serra e interpretamos um conjunto de relações que participam da dinâmica socioambiental da Serra da Gorongosa. 
A Serra da Gorongosa possui condições peculiarmente favoráveis, enquanto área detentora de uma biodiversidade e sociodiversidade notáveis, para se tornar em área de geoconservação capaz de se constituir em um importante destino turístico e provocar o fluxo de capital financeiro para a região centro de Moçambique, em particular.

Não obstante a existência de conhecimento público sobre a importância histórica das comunidades locais na região centro de Moçambique, em 2010 a Serra da Gorongosa foi proclamada Área de Conservação Total e integrada no Parque Nacional da Gorongosa, através do Decreto 78/2010, de 31 de Dezembro, constituindo-se assim em uma expansão territorial dos limites do PNG.

O ato de criação da área de conservação torna praticamente nulos os direitos das comunidades locais vigentes até essa altura e não estão previstos outros direitos das comunidades secularmente estabelecidas na Serra da Gorongosa.

A perda do direito ao acesso e exploração dos recursos naturais pelas comunidades e aos lugares de veneração dos seus ancestrais (lugares sagrados) constituem os principais pontos de discórdia das comunidades locais, por interferirem negativamente na reprodução física e cultural das comunidades e, para os gestores ambientais do PNG, a presença das comunidades com as suas atividades extrativistas condiciona a gestão bem sucedida da área da área de conservação, o que cria a ideia aparente da existência de antagonismo entre a necessidade de se proteger a biodiversidade, em áreas protegidas e a presença das comunidades, com as suas práticas socioeconômicas.

A proibição da exploração direta dos recursos naturais pelas comunidades locais ${ }^{20}$ promove, de forma implícita, a desapropriação de territórios ocupados pelas comunidades desfavorecidas. A desapropriação do território coloca em evidência a noção de violação ao Princípio da Liberdade de Residência e de Circulação prevista na Constituição da República de Moçambique (2004), na qual se afirma que todos os cidadãos têm o direito de fixar residência em qualquer parte do território nacional ${ }^{21}$.

A separação das comunidades locais do seu meio não faz sentido para estas, pois é justamente desta relação de que depende a sua reprodução física e cultural. Com efeito, o território integra a dimensão política, sociocultural e econômica, o que torna difícil a separação das comunidades das áreas de conservação, ainda que as políticas públicas em Moçambique continuem a encarar o homem e natureza como opostos e se esforcem em formular estratégias de conservação que reforçam a produção da fragmentação da natureza.

\footnotetext{
20 Ponto 4, artigo 13, Secção I, Capíto III (Zonas de Protecção) da Lei no 16/2004, de 20 de Junho, Lei de Proteção, Conservação e Uso Sustentável da Diversidade Biológica.

21 Ponto 1 do artigo 55, do Capítulo II (Direitos, Deveres e Liberdade) da Constituição da República de 2004 e Ponto 3 , artigo 16 (Parque Nacional), Secção I, Capítulo III (Zonas de Proteção) da Lei no 16/2004, de 2o de Junho, Lei de Proteção, Conservação e Uso Sustentável da Diversidade Biológica.
} 
$\mathrm{Na}$ interpretação do ordenamento das práticas socioculturais e econômicas das comunidades, a Geografia permitiu-nos reconhecer, o espaço material e o espaço simbólico. A partir desta base, foi possível fazermos uma leitura do espaço encontrado na Serra da Gorongosa, tomando a política, a cultura e a economia, como eixos de análise, os quais exprimem os processos de estruturação e organização das comunidades locais e a materialidade que Ihes circunda e com a qual interagem permanentemente.

A Serra da Gorongosa constitui espaço de exercício de poder do Estado através da legislação e estratégias do poder político, no qual os diferentes interesses se confrontam com as normas instituídas e do poder tradicional com vista a afiançar a reprodução física e cultural das comunidades locais.

As atividades econômicas, na Serra, são periódicas e marcadas essencialmente por prática agrícola que passa pela alternância de cultivo, mas localizáveis. Distinguem-se das outras atividades socioeconômicas (exploração madeireira e prospecção mineira) praticadas fundamentalmente pelos vindouros. A caracterização das atividades econômicas foi espacializada pela categoria de superfície/área e as relações estabelecidas entre essas atividades e os seus praticantes resultam em diferenciações e desigualdades espaciais que refletem as distintas formas de organização do espaço. A organização do espaço, de acordo com a apropriação dos recursos naturais pelos diferentes atores sociais e da sua transformação em produtos alimentares e demais bens e mercadorias, constitui campo de estudo da Geografia.

A cultura também se manifesta através da distribuição espacial dos lugares sagrados ou Geosímbolos. Identificamos sete Geosímbolos, dentre vários que existem na Serra da Gorongosa. As visita aos Geossítios, demonstram que existe uma relação entre o espaço e o imaginário das comunidades locais que reflete a ligação das dimensões material e imaterial.

A sobreposição permite-nos assim, percebermos como o lugar, o espaço e o território são qualificados a partir das suas distintas ordens organizativas, as quais nos oferecem uma nova estrutura de pensamento baseada no reconhecimento da importância da interdependência complexa entre a sociedade e a natureza, através da interação entre o mundo material e suas significações e, por via disso, compreendermos a complexidade das discórdias sociais na Serra da Gorongosa. 


\section{REFERÊNCIAS}

ADG (ADMINISTRAÇÃO DISTRITAL DA GORONGOSA). Plano Estratégico Distrital de Desenvolvimento de Gorongosa. Moçambique, 2006.

DIEGUES, Antônio Carlos, ARRUDA, Rinaldo S. V. Saberes tradicionais e biodiversidade no Brasil, São Paulo: Ministério do Meio Ambiente, USP, 2001.

DOMINGOS, Luís Pereira. Avaliação da plantação florestal de espécies nativas na recuperação e conservação da Serra da Gorongosa. Trabalho de licenciatura, Maputo: Universidade Eduardo Mondlhane, Faculdade de Agronomia e Engenharia Florestal, Departamento de Engenharia Florestal, 2011.

DONDEYNE, Stefaan; NHACA, Fernando; JANTAR, Piano. Garimpo no Distrito de Gorongosa: Implicações para o Parque Nacional da Gorongosa. Moçambique, Chimoio: CDS-RN, 2007.

FERRO, B.P.A. e BOUMAN, D. Notícia explicativa da carta hidrogeológica na escala 1:1.000.000: Projecto da carta hidrológica de Moçambique com apoio da UNICEF. Moçambique: Ministério da Construção e Águas, Direção Nacional de Águas, 1987.

GIUDICE, Geodiversidade como estratégia de conservação territorial. In: SOUZA; Rosemeri M.; SILVA, Maria do Socorro F. Conservação ambiental e planejamento territorial: desafios da gestão e da participação social. 1a ed., Porto alegre: Redes Editora, 2013.

INSTITUTO NACIONAL DE ESTATíSTICA (INE). IV Recenseamento Geral da População, 2017. Resultados Definitivos, Província de Sofala, Moçambique, 2017.

INVEZ, Romeu e FREITAS, Ferraz de. O Grupo Sena. Lourenço Marques: Gabinete Provincial de Acção Psicológica. 1971.

JUNOD, Henri. Usos e costumes dos Bantus. Tomo II, Maputo: Arquivo Histórico de Moçambique, Documento 3, 1996.

LEFF, Enrique. Ecologia, Capital e Cultura: A territorialização da racionalidade ambiental. Editora Vozes, Brasil, Rio de Janeiro: 2009.

MAFALACUSSER, J.M. e MARQUES, M.R. O Potencial dos recursos agrários do distrito de Gorongosa e possibilidades de desenvolvimento: Programa de Desenvolvimento Rural, Sofala. Moçambique, Sofala: Direção Provincial de Agricultura e Desenvolvimento Rural, PRODER, 2000.

NOLASCO, E. C. Babel local. Lugares da miúdas culturas. Campo Grande: Life, 2010.

ROSENDAHL, Zeny. O Sagrado e sua Dimensão Espacial in Olhares Geográficos: Modos de ver e viver o Espaço. In: CASTRO, Iná Elias; GOMES, Paulo César da Costa; CORRÊA Roberto Lobato. Rio de Janeiro: Editora Bertrand Brasil Lda. 2012.

SACK, Robert D. Human Territoriality: Its theory and history. Cambridge: Cambridge University Press, 1986. 
SANTILLI, Juliana. Socioambientalismo e novos direitos: proteção jurídica a diversidade biológica e cultural. São Paulo: Petrópolis, Instituto Socioambiental de Educação do Brasil, 2005.

SANTOS, Gabriela Aparecida dos. Reino de Gaza: O Desafio português na ocupação do Sul de Moçambique (1821-1897). São Paulo, Brasil: Universidade de São Paulo, Faculdade de Filosofia, Letras e Ciências Humanas, Departamento de História, Programa de Pósgraduação em História Social. 2007.

SOTRATTI, Marcelo António; MARAFON, Glaucio José. Pesquisa qualitativa nos estudos do patrimônio cultural em espaços rurais: Desafios e possibilidades. In: VENTURI, Luis António Bittar (organizador). Geografia: Práticas de campo, laboratório e sala de aula. São Paulo: Editora Sarandi, 2011.

\section{Documentos Oficiais}

MOÇAMBIQUE. Constituição da República de Moçambique, 2004. Aprovado pela Assembleia da República aos 16 de Novembro de 2004.

MOÇAMBIQUE. Decreto no 78/2010 de 31 de Dezembro. Aprova o Alargamento dos limites do Parque Nacional da Gorongosa.

MOÇAMBIQUE. Lei n 16/2014, de 20 de Junho. Aprova os Princípios e Normas Básicas sobre a Proteção, Conservação, Restruturação e Utilização Sustentável da Diversidade Biológica nas Áreas de Conservação.

- MOÇAMBIQUE. Diploma Ministerial no 130/2006, de 19 de Julho. Aprova a Lei 5/2017, de 11 de Maio sobre Lei no 16/2014, de 20 de Junho (Lei de Proteção, Conservação, Restauração e Utilização Sustentável da Diversidade Biológica nas Áreas de Conservação). 